\title{
Carbohydrate chiral-pool approach to four enantiomerically pure 2-naphthylmethyl 3-hydroxy-2-methylbutanoates
}

\author{
Bogdan Doboszewski ${ }^{\mathrm{a}, \mathrm{b}, \dagger}$, Piet Herdewijn ${ }^{\mathrm{a}, *}$ \\ ${ }^{a}$ Laboratory of Medicinal Chemistry, Rega Institute for Medical Research, Katholieke Universiteit Leuven, Minderbroedersstraat 10,3000 Leuven, Belgium \\ ${ }^{\mathrm{b}}$ Departamento de Quimica, UFRPE, 52171-900 Recife, Brazil
}

\section{A R T I C L E I N F O}

Article history:

Received 28 February 2008

Received in revised form 26 March 2008

Accepted 26 March 2008

Available online 29 March 2008

\section{Keywords:}

Chiral pool

Fluorescent tag

Monosaccharides

Stereoselective

Stereospecific

\begin{abstract}
A B S T R A C T
D-Glucose, L-xylose, and D- and L-arabinose were sources of chirality to obtain four enantiomerically pure 3-hydroxy-2-methylbutanoic acids, which were reacted with 2-naphthyldiazomethane to furnish their fluorescent 2-naphthylmethyl esters.
\end{abstract}

(C) 2008 Elsevier Ltd. All rights reserved.

\section{Introduction}

Batumin 1, 2E,10Z,12E-20-(3-aminocarboxy)-2-methyl-1-oxobutylamino-7-methylene-17-oxo-19-oxy-3,5,15-trimethyleicosa-2, 10,12-trienoic acid, is an antibiotic produced by the strains of Pseudomonas batumici (Fig. 1). ${ }^{1}$ It shows very good activity particularly against Gram-negative bacteria, e.g., Staphylococcus aureus, ${ }^{2,3}$ which pose a serious health problem due to their resistance against antibiotics in current use. Batumin's basic structural elucidation was performed, except for establishing the configurations of the five stereogenic carbon centers. Compound which has the same gross molecular composition dubbed as kalimantacin A, was isolated from a fermentation broth of Alcaligenes sp. YL-02632S. Kalimantacin $A$ has the same set of configurations of the $\mathrm{C}=\mathrm{C}$ bonds but its absolute configurations remain unknown. ${ }^{4-6}$ It is not clear at this time if batumin and kalimantacin A are the same compounds or if they differ at the configurations of the stereogenic centers. In principle, compound $\mathbf{1}$ can be degraded in a basic medium to release 3-hydroxy-2-methylbutanoic acid 2 (Fig. 1). It should be possible to establish absolute configurations of 2 by chiral HPLC by comparison of its mobility with the four reference 3-hydroxy-2methylbutanoic acids, which have the known configurations. In this way, the configurations of the left fragment containing two

\footnotetext{
* Corresponding author. Tel.: +32 16 337387; fax: +32 16337340 .

E-mail address: piet.herdewijn@rega.kuleuven.be (P. Herdewijn).

On leave from the Departamento de Quimica.
}

stereogenic carbon atoms in $\mathbf{1}$ can be obtained, which would be an initial step to solve the still lacking full stereochemical constitution of 1.

Reported here is a carbohydrate-based chiral-pool approach to obtain all four enantiomerically pure (within accuracy of their ${ }^{1} \mathrm{H}$ and ${ }^{13} \mathrm{C}$ NMR spectra recorded at $500 \mathrm{MHz}$ and $125 \mathrm{MHz}$, respectively) 3-hydroxy-2-methylbutanoic acids 20, 33, 48, and 56 in a form of their fluorescent 2-naphthylmethyl esters. Preliminary results of this work were published. ${ }^{7}$

The syntheses of chiral $\mathbf{2}$ with variable enantiomeric purities were realized before via aldol condensations ${ }^{8-16}$ (in some cases enzymatic resolution step was involved ${ }^{8,9}$ ), enantioselective reductions of carbonyl group, ${ }^{17,18}$ or by acetoxymercuration followed by chiral resolution. 19

In this work, we opted for the application of monosaccharides to obtain the enantiomerically pure targets $20,33,48$, and 56 in order to avoid a necessity to perform chiral separations, which can be difficult. Additionally, the starting sugars have well-established absolute configurations, which assure that the targets have predictable stereochemistry.

\section{Results and discussion}

The basic idea of transformation of the starting sugars 1,$2 ; 5$, 6-di-O-isopropylidene-D-gluco-furanose 3, 5-O-tert-butyldimethylsilyl-1,2-O-isopropylidene-L-xylo-furanose 25, 5-O-tert-butyldiphenylsilyl-1,2-O-isopropylidene-D-arabino-furanose $\mathbf{3 5}$, and its 


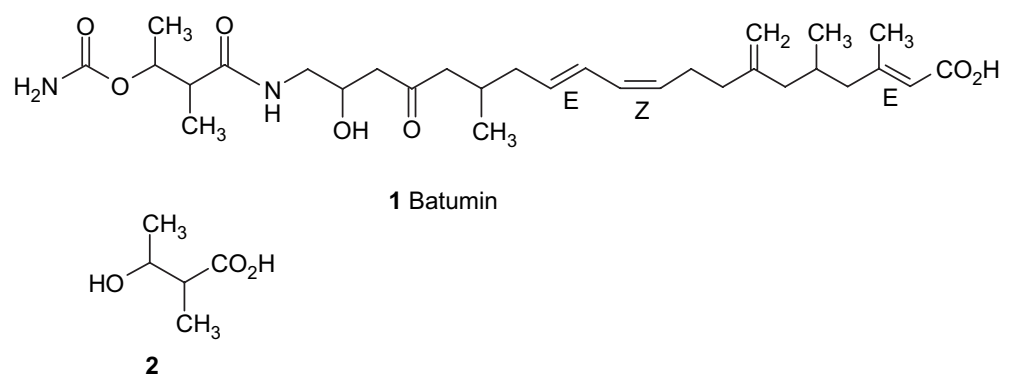

Figure 1. Structure of batumin and of 3-hydroxy-2-methylbutanoic acid, a possible degradation product of batumin.

L-enantiomer 49 into the targets $\mathbf{2 0}, \mathbf{3 3}, \mathbf{4 8}$, and $\mathbf{5 6}$, respectively, is shown in Figure 2. In all four cases, the stereocenters at the atoms $\mathrm{C} 4$ in the substrates were preserved and the bulky 1,2-O-isopropylidene moieties were used to install predictably the C3 methyl groups in the intermediates $\mathbf{7}, \mathbf{2 8}, \mathbf{3 9}$, and 54 via oxidation, Wittig methylenation, and hydrogenation. In the case of D- and L-arabinose, this sequence was $100 \%$ stereoselective, whereas for D-glucose $\mathbf{3}$ and L-xylose $\mathbf{2 5}$ the selectivity was ca. 90\%, however, a simple crystallization furnished pure stereoisomers at the $\mathrm{C} 3$ at a later stage (see below). The lateral groups attached to $\mathrm{C} 4$ in the substrates were transformed into the methyl groups and the $\mathrm{C} 2$ atoms functioned as the latent carboxyl groups.

The synthesis of the $(2 R, 3 R)$ compound $\mathbf{2 0}$ is shown in Scheme 1. Commercial 1,2;5,6-di- $O$-isopropylidene- $D$-gluco-furanose 3 was oxidized to 4 using $\mathrm{CrO}_{3}-\mathrm{Py}-\mathrm{Ac}_{2} \mathrm{O}$ system by analogy to the other oxidations $^{20,21}$ and subjected to Wittig methylenation to give $\mathbf{5}$. Catalytic hydrogenation over $\mathrm{Pd}-\mathrm{C}$ rather than $\mathrm{RaNi}^{22}$ furnished a separable mixture of 6 and 7 in a proportion ca. $1: 10$ by ${ }^{1} \mathrm{H}$ NMR (roughly the same proportion of $\mathbf{6}$ to $\mathbf{7}$ was obtained using much more synthetically demanding thiol-catalyzed free-radical redox process), ${ }^{23}$ and an unexpected monoisopropylidenated compound 8. Cleavage of 5,6-acetonide was most probably a result of the presence of small quantity of $\mathrm{PdCl}_{2}$ in the batch of the catalyst. In a hydrogen atmosphere, $\mathrm{PdCl}_{2}$ was reduced to liberate $\mathrm{HCl}$, which cleaved the more reactive 5,6-acetonide. The same explanation was given to rationalize the alleged hydrogenolysis of the tert-butyldimethylsilyl ethers, which eventually turned out to be a simple hydrolysis. $^{24,25}$ The D-allo stereoisomer 7 was isolated by flash chromatography and subjected to 'dehomologation, 26,27 ((a) $\mathrm{H}_{5} \mathrm{IO}_{6}$ EtOAc and (b) $\mathrm{NaBH}_{4}-\mathrm{EtOH}$ ) to give 3-deoxy-3-C-methyl-D-ribo epimer 10 via the aldehyde 9. Conventional tosylation furnished a highly crystalline 11, which served as a substrate for 'deoxygenative substitution' $\left(-\mathrm{CH}_{2} \mathrm{OTs} \rightarrow-\mathrm{CH}_{3}\right)$ using $\mathrm{LiBH}(\mathrm{Et})_{3}$ to get another methyl group $(\mathbf{1 1} \rightarrow \mathbf{1 3})$. Since chromatographic separation of $\mathbf{6}$ and $\mathbf{7}$ was inconvenient, the 'dehomologation' step was performed on the mixture $\mathbf{6}$ and $\mathbf{7}$ obtained after hydrogenation of $\mathbf{5}$ over Adam's catalyst $\left(\mathrm{PtO}_{2}\right)$. The mixture of both epimeric compounds 12 thus obtained was subjected to tosylation and crystallization from EtOAc. This simple crystallization step furnished a pure D-ribo compound $\mathbf{1 1}$ in 54\% yield counting on $\mathbf{6}$ and 7. The

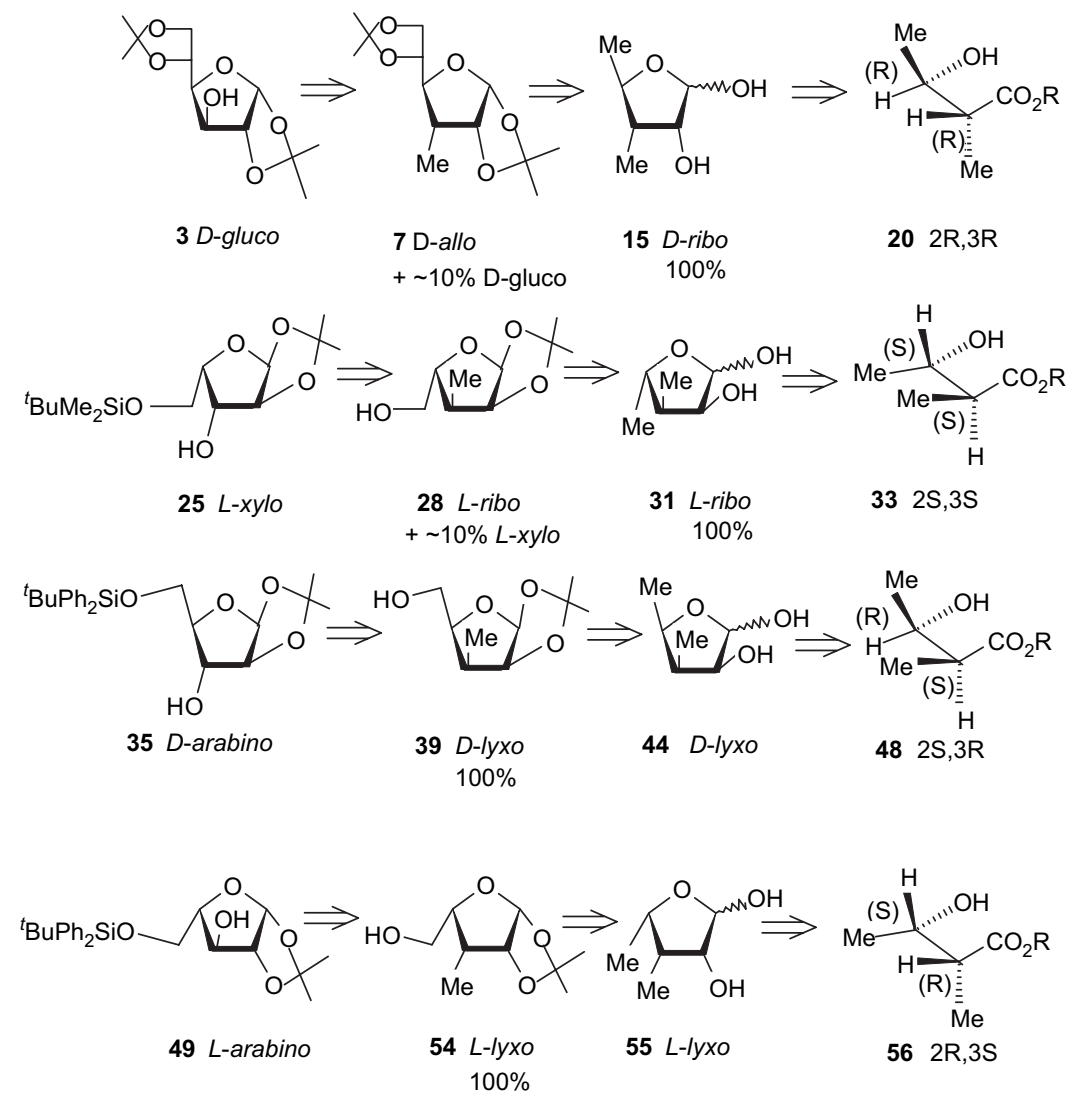

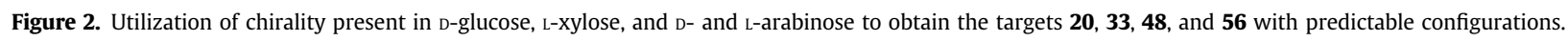



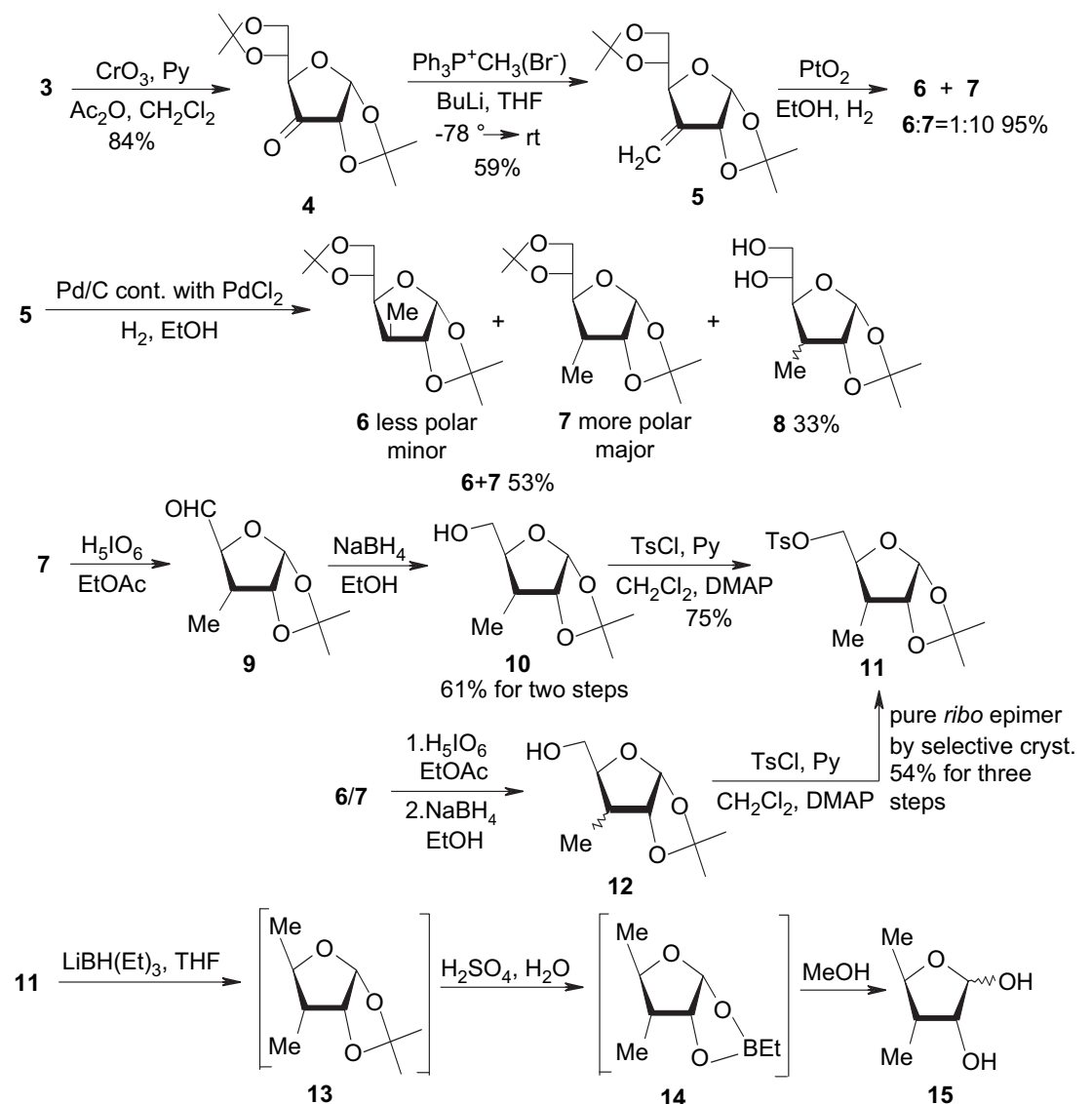

13

tentative structure

15
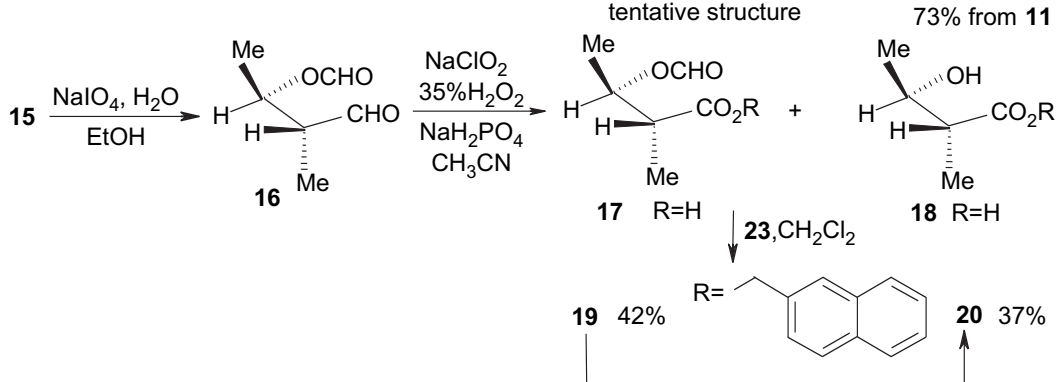

$\mathrm{NH}_{4} \mathrm{OH}, \mathrm{MeOH}, 89 \%$

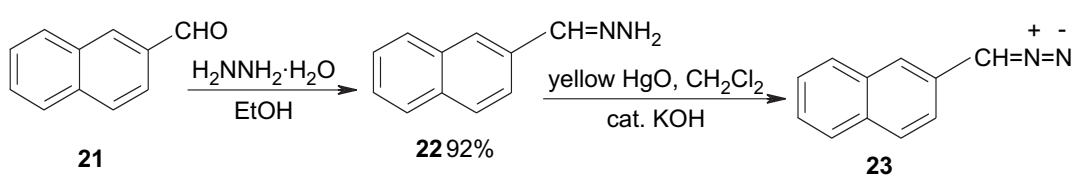

Scheme 1. Obtention of 2-naphthylmethyl (3R)-hydroxy-(2R)-methylbutanoate $\mathbf{2 0}$ from D-glucose.

configuration $(3 R)$ in the tosylate $\mathbf{1 1}$ was confirmed by X-ray analysis. ${ }^{28}$ Tosylate $\mathbf{1 1}$ was then treated with $\mathrm{LiBH}(\mathrm{Et})_{3}$, a donor of a very soft 'supernucleophilic' hydrogen anion, to give 3,5-dideoxy3-C-methyl-1,2-O-isopropylidene-D-ribo-furanose 13. Tronchet and Graf described a different route to 13 starting from 3,5-dideoxy-1,2$O$-isopropylidene-3C-(E,Z)-methylthiomethylene- $\alpha$-D-erythro-pentofuranose by RaNi hydrogenation/desulfurization followed by preparative gas chromatography to separate it from the C3 D-xylo epimer. ${ }^{29}$ The isolation of $\mathbf{1 3}$ was skipped and acid hydrolysis of the 1,2-acetonide function was performed by the addition of aq $\mathrm{H}_{2} \mathrm{SO}_{4}$ directly to the reaction mixture still containing the boron compounds to give the diol $\mathbf{1 5}$ presumably via a cyclic borate $\mathbf{1 4}$ (see Section 3). Borates derived from vicinal diols are known to be quite stable, e.g., they survive on $\mathrm{HBr}-\mathrm{AcOH}$ or $\mathrm{PBr}_{3}$ treatment but can be easily cleaved by methanolysis. ${ }^{30}$ Consequently, repeated co- evaporations of the extracts with $\mathrm{MeOH}$ furnished 3,5-dideoxy 3-Cmethyl-D-ribo-furanose 15 isolated in $73 \%$ counting on 11. (Two alternative procedures to remove the isopropylidene function in 13: $\mathrm{I}_{2}-\mathrm{MeOH}^{31}$ and $\mathrm{FeCl}_{3} \cdot 6 \mathrm{H}_{2} \mathrm{O}-\mathrm{CH}_{2} \mathrm{Cl}_{2}$, ${ }^{32}$ were inefficient.) In this way, both methyl groups were properly installed and the carboxyl group was ready to be formed. The vicinal diol system in $\mathbf{1 5}$ was cleaved with $\mathrm{NaIO}_{4}$ to give the transient aldehyde 16, which was immediately subjected to oxidation using $\mathrm{NaClO}_{2}-\mathrm{H}_{2} \mathrm{O}_{2}-\mathrm{NaH}_{2} \mathrm{PO}_{4}$ system. ${ }^{33}$ TLC at this stage showed two products: a major formyloxy acid 17 and a minor more polar hydroxy acid 18, visualized as yellow spots on a blue background upon revelation with an acidbase indicator bromocresol green. ${ }^{34,35}$ Both $\mathbf{1 7}$ and $\mathbf{1 8}$ were not isolated, but instead they were esterified with freshly prepared 2-naphthyldiazomethane $\mathbf{2 3}$ obtained from the hydrazone $\mathbf{2 2}^{36}$ by $\mathrm{KOH}$ catalyzed $\mathrm{HgO}$ oxidation by analogy to the other 
arylhydrazones. ${ }^{37,38}$ The esterifications with $\mathbf{2 3}$ can be referred to as titrations: loss of the red-orange color of a $\mathrm{CH}_{2} \mathrm{Cl}_{2}$ solution of $\mathbf{2 3}$ was nearly instantaneous and was accompanied by evolution of nitrogen. Addition of $\mathbf{2 3}$ was stopped when a reddish color indicating the presence of the excess of $\mathbf{2 3}$ persisted. The procedure routinely took ca. 1-2 min. TLC of these mixtures showed a strong fluorescent spot of the formate $\mathbf{1 9}$ (major) and a more polar 2naphthylmethyl (3R)-hydroxy-(2R)-methylbutanoate 20 (minor), accompanied by UV absorbing compounds having $R_{f} s$ values similar to those of 19. The presence of these impurities was not surprising since it is known that in situ generated aryl diazomethanes are in general not more than $85 \%$ pure, ${ }^{39}$ and also the transient naphthylmethyl carbenes can decompose to form by-products.

It should be pointed out that tagging of the organic acids with fluorescent 1-napthylmethyl or 1-napthylethyl groups was applied to facilitate their detections during HPLC analysis. ${ }^{40}$ Both 19 and the target $\mathbf{2 0}$ could be isolated at this stage, and the formate $\mathbf{1 9}$ could be easily transformed to $\mathbf{2 0}$ by ammonolysis using aq $\mathrm{NH}_{4} \mathrm{OH}$ in $\mathrm{MeOH}$. However, it was much more convenient to perform this deprotection on a crude esterification mixture and to isolate $\mathbf{2 0}$ in a cumulative yield of ca. 70\% for four steps counting on the diol $\mathbf{1 5}$. Comparison of the ${ }^{1} \mathrm{H}$ and ${ }^{13} \mathrm{C}$ NMR spectra of the $(2 R, 3 R)$ target 20 with those of the $(2 S, 3 R)$ epimer $\mathbf{4 8}$ (see below) showed that no inversion of configuration at the $\mathrm{C} 2$ atom via enolization took place during this sequence and that $\mathbf{2 0}$ is a pure enantiomer within the limits of the $500 \mathrm{MHz}\left({ }^{1} \mathrm{H}\right)$ and $125 \mathrm{MHz}\left({ }^{13} \mathrm{C}\right)$ measurements.

The enantiomeric $(2 S, 3 S)$ product 33 was obtained from L-xylose as shown in Scheme 2. 1,2-O-Isopropylidene-L-xylo-furanose $\mathbf{2 4}$ was prepared in a one-pot reaction by analogy to the D-enantiomer. ${ }^{41}$ Selective protection of the primary $\mathrm{OH}$ group by silylation $(\rightarrow \mathbf{2 5})$ by analogy to its D-enantiomer, ${ }^{27,42}$ followed by $\mathrm{CrO}_{3}-$ $\mathrm{Py}-\mathrm{Ac}_{2} \mathrm{O}$ oxidation and Wittig methylenation as described before $(\mathbf{3} \rightarrow \mathbf{4} \rightarrow \mathbf{5})$ furnished the olefin $\mathbf{2 6}$. Conventional desilylation and hydrogenation over Adam's catalyst furnished inseparable mixture of the major ( $\sim 90 \%)$ L-ribo epimer $\mathbf{2 8}$ and the L-xylo epimer 29, formed in the same proportion as compounds allo $\mathbf{7}$ and gluco $\mathbf{6}$. Tosylation of this mixture and subsequent crystallization furnished pure C3 L-ribo epimer 30, which is an enantiomer of D-compound 11 described above. Obviously, the NMR data of $\mathbf{3 0}$ match with those of $\mathbf{1 1}$ and both compounds have the opposite optical rotations. Transformation of $\mathbf{3 0}$ to the diol $\mathbf{3 1}$ and further to 2-naphthylmethyl (3S)-hydroxy-(2S)-methylbutanoate 33 proceeded exactly as described above for the D-series. Again, both $(2 S, 3 S) \mathbf{3 3}$ and $(2 R, 3 R) \mathbf{2 0}$ differ only in the sign of their optical rotations.

The other two targets, which have $(2 S, 3 R)$ and $(2 R, 3 S)$ configuration, viz. 48 and $\mathbf{5 6}$, respectively, were obtained in a stereospecific way using D-arabinose (Scheme 3) and L-arabinose (Scheme 4). Selective tert-butyldiphenylsilylation of D-arabinose followed by isopropylidenation was performed by analogy to the known process described for L-arabinose $\mathrm{e}^{20,21}$ to furnish tert-butyldiphenylsilyl-1,2-O-isopropylidene-D-arabino-furanose $35 .{ }^{43}$ Oxidation at the position $\mathrm{C} 3$ followed by Wittig methylenation furnished the olefin 36. Tebbe's reagent ( $\mu$-chloro- $\mu$-methylene[bis(cyclopentadienyl)titanium]-dimethylaluminum) could also be used, ${ }^{21}$ but its price is rather high. Two-step Peterson olefination ((1) $\mathrm{Me}_{3} \mathrm{SiCH}_{2} \mathrm{Li}$ and (2) $\mathrm{NaH}$ ) was an alternative, ${ }^{21}$ but a single step Wittig reaction seemed to be the simplest, and permitted the obtention of $\mathbf{3 6}$ in 72\% yield for two steps. Desilylation furnished 37, which was subjected to hydrogenation over Adam's catalyst to furnish two products. The less polar $\mathbf{3 8}$ had a double bond migrated to the 3,4-position and was isolated in $13 \%$ yield, whereas the necessary 3-deoxy-1,2-O-isopropylidene-3-C-methyl-D-lyxofuranose 39 was obtained in 71\% yield. Formation of $\mathbf{3 8}$ undoubtedly reflects a steric difficulty to install four syn oriented substituents inside a lyxofuranosyl ring. At the same time, it is known that tetrasubstituted olefins are quite resistant toward hydrogenation, ${ }^{44}$ so persistence of $\mathbf{3 8}$ under such conditions is not surprising. The alcohol 39 was converted to its 5-O-tosylate 40, which, however, turned out to be unreactive toward substitution using $\mathrm{LiBH}(\mathrm{Et})_{3}$. This inertness again reflects a steric congestion in the lyxo ring in 40. The triflate 41, however, reacted with $\mathrm{LiBH}(\mathrm{Et})_{3}$ to give $\mathbf{4 2}$ even though decomposition was visible on TLC. Further steps to obtain the 3,5-dideoxy-3-C-methyl-D-lyxofuranose $\mathbf{4 4}$ proceeded as described above for the $\mathrm{D}-$ ribo $(\mathbf{1 1} \rightarrow \mathbf{1 5})$ and L-ribo $(\mathbf{3 0} \rightarrow \mathbf{3 1})$ series. It is evident that a combination of the best known leaving group (-OTf) and a supernucleophilic properties of the $\mathrm{LiBH}(\mathrm{Et})_{3}$ partly offsets the steric hindrance in $\mathbf{4 1}$, even though a yield of the isolated $\mathbf{4 4}$ was $27 \%$, much less than in the case of the less congested compounds $\mathbf{1 1}$ and 30. It should be pointed out that application of the triflate $\mathbf{4 5}$, which is less congested than $\mathbf{4 1}$ due to lack of the $C 3$ methyl group, did not improve the yield of $\mathbf{4 4}$ (data not shown). Further transformation of $\mathbf{4 4}$ proceeded following the procedure

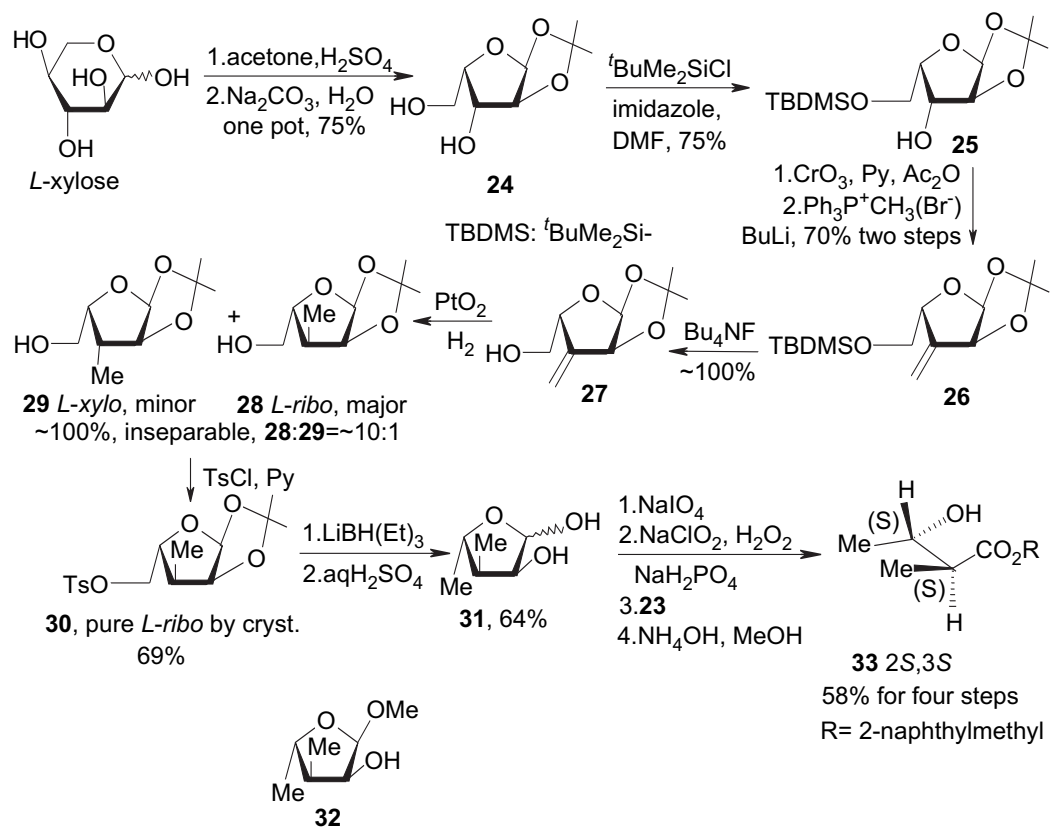

Scheme 2. Obtention of 2-naphthylmethyl (3S)-hydroxy-(2S)-methylbutanoate 33 from L-xylose. 

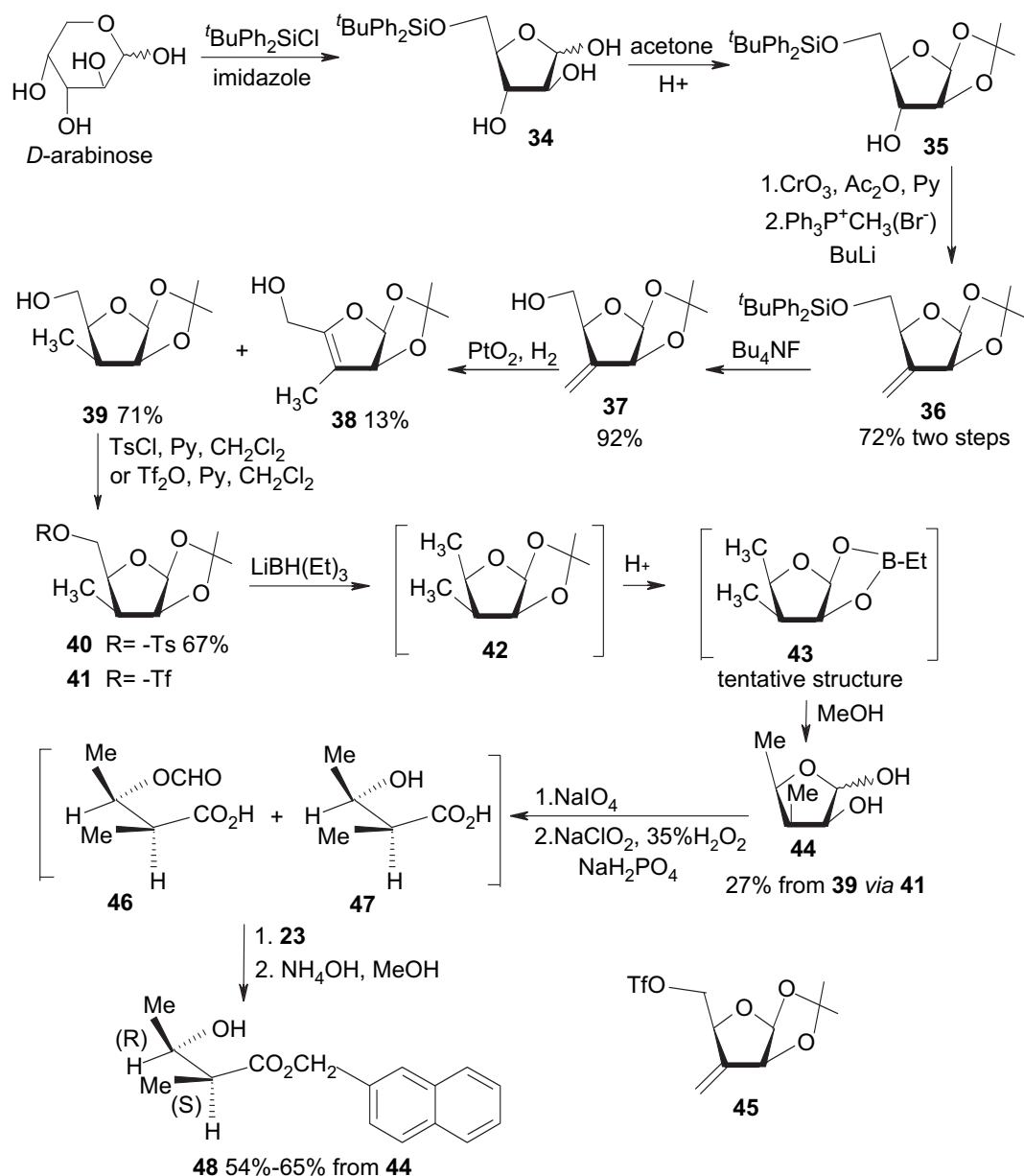

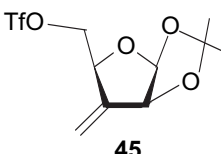

45

Scheme 3. Obtention of 2-naphthylmethyl (3R)-hydroxy-(2S)-methylbutanoate 47 from D-arabinose.

used above $(\mathbf{1 5} \rightarrow \mathbf{2 0}$ and $\mathbf{3 1} \rightarrow \mathbf{3 3}$ ) via the intermediates $\mathbf{4 6}$ and $\mathbf{4 7}$, which were deformylated without separation to furnish the third target 2-naphthylmethyl (3R)-hydroxy-(2S)-methylbutanoate $\mathbf{4 8}$.

The last target $\mathbf{5 6}$, which has $(2 R, 3 S)$ configuration was obtained from L-arabinose (Scheme 4) following the same directions as those applied to D-arabinose, starting with the known tert-butyldiphenylsilyl-1,2-O-isopropylidene-L-arabino-furanose $\mathbf{4 9}^{20,21}$ via the olefin 50 with two noticeable differences. Firstly, attempted hydrogenation of $\mathbf{5 0}$ over $\mathrm{Pd}-\mathrm{C}$ catalyst resulted in migration of the carbon-carbon double bond in a much higher extend than in the

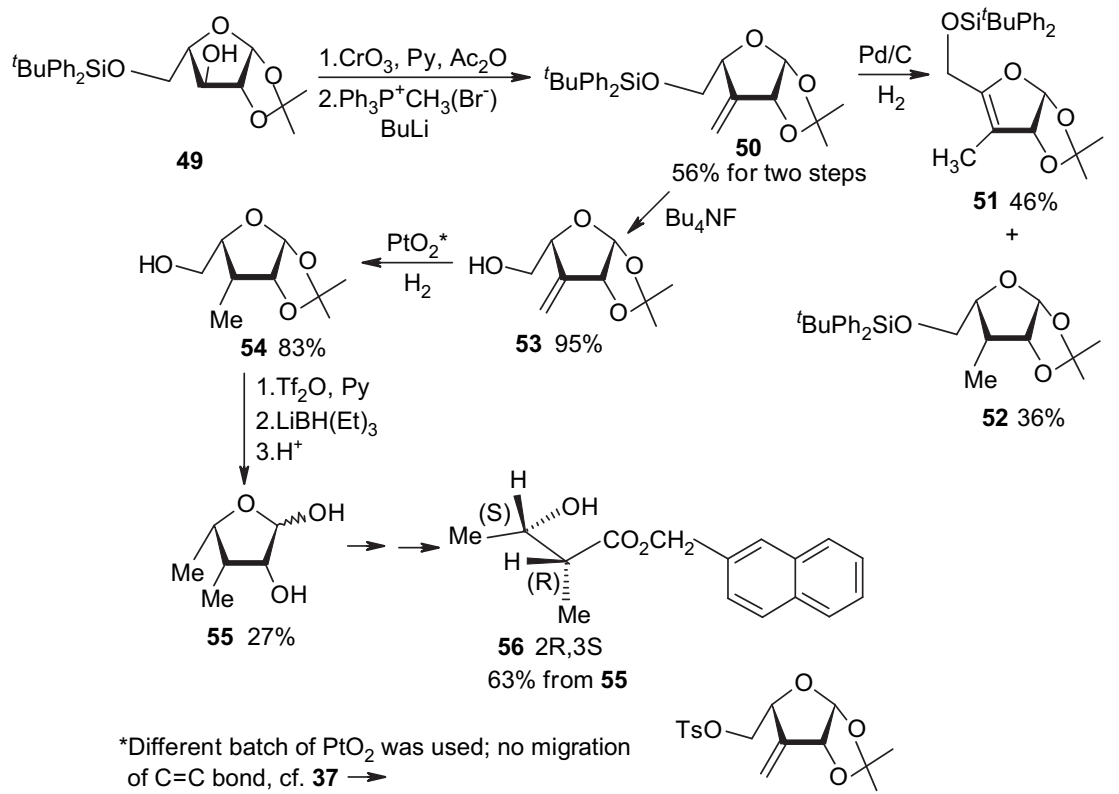

Scheme 4. Obtention of 2-naphthylmethyl (3S)-hydroxy-(2R)-methylbutanoate $\mathbf{5 6}$ from L-arabinose. 
case of the desilylated D-compound 37, and the unwanted olefin $\mathbf{5 1}$ was obtained in $46 \%$ yield, whereas the necessary L-lyxo-3-Cmethyl product 52 was obtained in $36 \%$ yield. This was presumably a result of a bulk of the tert-butyldiphenylsilyl group. Also, palladium promotes migrations of the $\mathrm{C}=\mathrm{C}$ bonds to a greater extent than platinum. ${ }^{45}$ Secondly, hydrogenation of the desilylated intermediate $\mathbf{5 3}$ over Adam's catalyst (a different batch of $\mathrm{PtO}_{2}$ was used than the one for hydrogenation of 37 ) resulted in the absence of the transposition of the $\mathrm{C}=\mathrm{C}$ bond and permitted isolation of the necessary C3-Me-L-lyxo product $\mathbf{5 4}$ in $\mathbf{8 3} \%$ yield. These subtle differences probably reflect variations of the properties of surfaces of platinum catalyst.

It should be pointed out that a tosylate $\mathbf{5 7}$ was unreactive toward $\mathrm{LiBH}(\mathrm{Et})_{3}$ just like the more congested $\mathbf{4 0}$.

Further transformation of the alcohol 54 to 3,5-dideoxy-3C-methyl-L-lyxofuranose $\mathbf{5 5}$ and its subsequent conversion to 2naphthylmethyl (3S)-hydroxy-(2R)-methylbutanoate $\mathbf{5 6}$ proceeded exactly as described for their enantiomeric equivalents.

In summary, all four enantiomerically pure 3-hydroxy-2-methylbutanoic acids as fluorescent 2-naphthylmethyl esters were synthesized starting from easily available carbohydrates.

The application of the targets $20,33,48$, and 56 to establish absolute configurations of the degradation product $\mathbf{2}$ after its conversion to 2-naphthylmethyl ester will be published in due course.

\section{Experimental}

\subsection{General}

All glasswares were dried at $104^{\circ} \mathrm{C}$. Evaporations were performed on a Büchi evaporator coupled to a membrane pump. Vacuums were broken using a balloon filled with nitrogen in the case of moisture-sensitive products. Moisture-sensitive liquids were transferred using dry syringes under atmosphere of nitrogen or argon. THF was freshly distilled from sodium-benzophenone. $\mathrm{CH}_{2} \mathrm{Cl}_{2}$ was dried by distillation from $\mathrm{P}_{2} \mathrm{O}_{5}$. Anhydrous acetone was prepared by shaking with $\mathrm{P}_{2} \mathrm{O}_{5}$ for ca. 20 min, filtration, and distillation. Dry DMF containing molecular sieves was obtained from Aldrich. NMR spectra were recorded on a Bruker $300 \mathrm{MHz}$ and Bruker Avance II $500 \mathrm{MHz}$ spectrometers using $\mathrm{CDCl}_{3}$-TMS unless otherwise stated. Electron impact exact mass measurements were performed on the MS5OTS Kratos instrument at $50 \mathrm{eV}$, whereas the electrospray measurements on the APEX-Qe Bruker instrument. Optical rotations were taken on a Perkin-Elmer 341 automatic polarimeter in $\mathrm{CHCl}_{3}$ (distilled from $\mathrm{P}_{2} \mathrm{O}_{5}$, i.e., ethanol-free) using a 1-dm tube for Na line at ca. $24^{\circ} \mathrm{C}$. Flash chromatography was performed using a $230-400$ mesh silica gel from ICN or Acros. TLC plates (Fluka) with a fluorescent indicator were used for analysis of the reaction mixtures. The chromatograms were visualized using $10 \% \mathrm{H}_{2} \mathrm{SO}_{4}$ in $\mathrm{MeOH}$ unless otherwise stated and charring at 120$130{ }^{\circ} \mathrm{C}$. 'Bromocresol green reagent' used for detection of the carboxylic acids means $0.4 \%$ solution of bromocresol green in EtOH and $0.1 \mathrm{~N}$ aq $\mathrm{NaOH}$ added just to change a color to blue. ${ }^{34,35}{ }^{\prime} \mathrm{CrO}_{3}-$ $\mathrm{H}_{2} \mathrm{SO}_{4}$ system' means $2 \% \mathrm{CrO}_{3}$ in $10 \% \mathrm{H}_{2} \mathrm{SO}_{4}$. 'Xylene' means a mixture of isomers. Pyridine was stored over pellets of $\mathrm{KOH}$. Dry ethyl acetate was prepared by distillation. Early distillate containing azeotropic mixture with water was rejected and the late fraction was used. $\mathrm{Na}_{2} \mathrm{SO}_{4}$ was used to dry the extracts.

\subsection{3-Deoxy-1,2;5,6-di-O-isopropylidene-3-C-methylene- D-ribo-hexofuranose 5}

To a magnetically stirred mixture of $\mathrm{CrO}_{3}(10.0 \mathrm{~g}, 100 \mathrm{mmol})$ in $100 \mathrm{ml}$ of dry $\mathrm{CH}_{2} \mathrm{Cl}_{2}$ was added pyridine $(16.2 \mathrm{ml}, 200 \mathrm{mmol})$ under nitrogen. The mixture immediately turned dark brown and became warm again. Nearly all $\mathrm{CrO}_{3}$ solubilized. After $30 \mathrm{~min}$, solid 1,2;5,6-di-O-isopropylidene-D-gluco-furanose 3 (6.55 g, $25.2 \mathrm{mmol}$ ) was added immediately followed by $\mathrm{Ac}_{2} \mathrm{O}(9.8 \mathrm{ml}, 100 \mathrm{mmol})$. The mixture became warm again. TLC in 2:1 hexane-EtOAc after $45 \mathrm{~min}$ showed an elongated spot of the ulose 4 , which is slightly more polar than 3. Most of $\mathrm{CH}_{2} \mathrm{Cl}_{2}$ was evaporated. Addition of $100 \mathrm{ml}$ of 1:1 toluene-EtOAc mixture precipitated most of the chromium compounds. The decanted solution and the washings of the precipitated black solid tar were pushed through a 60-200 mesh silica gel column prepared in 1:2 toluene-EtOAc using an overpressure. Elution with 1:2 toluene-EtOAc, evaporation, co-evaporation with xylenes, and final drying furnished 4 $(5.44 \mathrm{~g}, 84 \%)$, which was used for a Wittig reaction without characterization.

A magnetically stirred suspension of methyltriphenylphosphonium bromide $(98 \%, 10.7 \mathrm{~g}, 30 \mathrm{mmol})$ in THF $(100 \mathrm{ml})$ under nitrogen with EtOH-dry ice external cooling was treated with $2.5 \mathrm{M} n$-BuLi in hexane $(11.2 \mathrm{ml}, 28 \mathrm{mmol})$ dropwise. The mixture turned yellow. After the addition of $n-\mathrm{BuLi}$, cooling was stopped for $30 \mathrm{~min}$ and re-applied again. A solution of 4 in $60 \mathrm{ml}$ of THF was added dropwise for ca. $10 \mathrm{~min}$. Cooling bath was removed. After $1.5 \mathrm{~h}$, TLC showed that all 4 reacted forming a less polar 5 with $R_{f} 0.36$ in 9:1 hexane-EtOAc. The solids were filtered on a sintered glass. Evaporation and flash chromatography in 9:1 hexane-EtOAc gave 5 ( $3.2 \mathrm{~g}, 59 \%$ counted on 4$)$ as a colorless oil. $[\alpha]_{\mathrm{D}}^{24}+109.4$ (c 2.6, $\left.\mathrm{CHCl}_{3}\right)$.

${ }^{1} \mathrm{H}\left(\mathrm{CDCl}_{3}, 300 \mathrm{MHz}\right): 5.81\left(\mathrm{~d}, J_{12}=4.0 \mathrm{~Hz}, 1 \mathrm{H}, \mathrm{H} 1\right), 5.50$ (dd, $\left.J=1.3,1.8 \mathrm{~Hz}, 1 \mathrm{H},=\mathrm{CH}_{2}\right), 5.45\left(\mathrm{dd}, J=0.8,2.2 \mathrm{~Hz}, 1 \mathrm{H},=\mathrm{CH}_{2}\right), 4.89$ (apparent dd, $\left.J=1.0 \mathrm{~Hz}, J_{21}=4.0 \mathrm{~Hz}, 1 \mathrm{H}, \mathrm{H} 2\right), 4.67-4.64(\mathrm{~m}, 1 \mathrm{H})$, 4.09-4.03 (m, 2H), 3.97-3.90 (m, 1H), 1.52, 1.44, 1.37, and 1.36 (four $\mathrm{s}, 3 \mathrm{H}$ each, isopropylidene $\mathrm{Me}) .{ }^{13} \mathrm{C}(75 \mathrm{MHz}): 146.8,113.4,112.5$, 109.7, 104.5, 82.1, 79.2, 77.3, 66.7, 27.3, 27.0, 26.5, 25.4 .

\subsection{3-Deoxy-1,2;5,6-di-O-isopropylidene-3-C-methyl-D-gluco- furanose 6, 3-deoxy-1,2;5,6-di-O-isopropylidene-3-C-methyl- D-allo-furanose 7, and 3-deoxy-1,2-0-isopropylidene-3- C-allo/gluco-furanose 8}

\subsubsection{Hydrogenation of $\mathbf{5}$ using $\mathrm{Pd}-\mathrm{C}$ contaminated with $\mathrm{PdCl}_{2}$}

To a solution of $5(3.2 \mathrm{~g}, 12.5 \mathrm{mmol})$ in $\mathrm{EtOH}(20 \mathrm{ml}, 96 \%)$ was added Pd-C (0.31 g 10\%) under a blanket of argon. Hydrogenation was performed in a Parr apparatus at the initial pressure of $35 \mathrm{psi}$. After $7 \mathrm{~h}$ of shaking, TLC showed the presence of the minor $\mathbf{6}$, slightly less polar than the major $\mathbf{7}\left(R_{f}\right.$ of a mid-point was 0.40 in 9:1 hexane-EtOAc, run twice), and $\mathbf{8}$ at a start. $R_{f}$ of $\mathbf{8}$ was 0.44 in 20:1 $\mathrm{CH}_{2} \mathrm{Cl}_{2}-\mathrm{MeOH}$. The mixture was passed through a bed of Celite (attention: used Pd catalyst is pyrophoric and should not be left dry) and the solvent was evaporated. Flash chromatography in 20:3 hexane-EtOAc gave $0.07 \mathrm{~g}$ of $\mathbf{6}, 0.02 \mathrm{~g}$ of a mixture of $\mathbf{6}$ and 7 , and $0.72 \mathrm{~g}$ of 7. Total yield of $\mathbf{6}$ and 7 was 53\%. Further elution with 20:1 $\mathrm{CH}_{2} \mathrm{Cl}_{2}-\mathrm{MeOH}$ gave $8(0.89 \mathrm{~g}, 33 \%)$

\subsubsection{Hydrogenation of 5 using $\mathrm{PtO}_{2}$}

To a solution of $\mathbf{5}(7.39 \mathrm{~g}, 28.9 \mathrm{mmol})$ in $20 \mathrm{ml}$ of $96 \%$ EtOH was added $\mathrm{PtO}_{2} \cdot \mathrm{H}_{2} \mathrm{O}(0.33 \mathrm{~g})$. Hydrogenation in a Parr apparatus at the initial pressure of 40 psi for $7 \mathrm{~h}$ followed by filtration through Celite (attention: used Pt is pyrophoric and should not be left dry) and evaporation furnished $7.11 \mathrm{~g}, 95 \%$ of a mixture 6 and 7. This mixture was used in a dehomologation step without chromatography.

Compound 6. ${ }^{1} \mathrm{H}(300 \mathrm{MHz}): 5.78\left(\mathrm{~d}, J_{12}=3.5 \mathrm{~Hz}, 1 \mathrm{H}, \mathrm{H} 1\right), 4.36(\mathrm{~d}$, $\left.J_{21}=3.5 \mathrm{~Hz}, 1 \mathrm{H}, \mathrm{H} 1\right), 4.13(\mathrm{dd}, J=5.4,7.9 \mathrm{~Hz}, 1 \mathrm{H}), 4.09-3.99(\mathrm{~m}, 2 \mathrm{H})$, $3.94(\mathrm{dd}, J=5.4,7.9 \mathrm{~Hz}, 1 \mathrm{H}), 2.45\left(\mathrm{dq}, J_{34}=4.0 \mathrm{~Hz}, J_{\mathrm{H} 3-\mathrm{Me}}=7.4 \mathrm{~Hz}, 1 \mathrm{H}\right.$, H3), 1.52, 1.41, 1.35, 1.31(four s, 3H each, isopropylidene Me), 0.96 (d, $\left.\mathrm{J}_{\mathrm{Me}-\mathrm{H} 3}=7.5 \mathrm{~Hz}, 3 \mathrm{H}, \mathrm{C} 3-\mathrm{Me}\right) .{ }^{13} \mathrm{C}(75 \mathrm{MHz}): 111.2,109.2,104.8,86.5$, 80.7, 73.5, 68.4, 40.6, 26.8, 26.7, 26.1, 25.3, 11.1 . 
Compound 7. ${ }^{1} \mathrm{H}(300 \mathrm{MHz}): 5.76\left(\mathrm{~d}, J_{12}=3.6 \mathrm{~Hz}, 1 \mathrm{H}, \mathrm{H} 1\right), 4.55(\mathrm{t}$, $J=4.2 \mathrm{~Hz}, 1 \mathrm{H}, \mathrm{H} 2$ ), 4.11-4.02 (m, 2H), 3.97-3.89 (m, 1H), 3.73 (ddd, $J=3.6,6.9,13.6 \mathrm{~Hz}, 1 \mathrm{H}), 1.95\left(\mathrm{ddq}, J_{32}=4.7 \mathrm{~Hz}, J_{34}=9.7 \mathrm{~Hz}, J_{\mathrm{H} 3-\mathrm{Me}}=\right.$ $6.8 \mathrm{~Hz}, 1 \mathrm{H}, \mathrm{H} 3$ ) $, 1.51,1.43,1.35,133$ (four $\mathrm{s}, 3 \mathrm{H}$ each, isopropylidene $\mathrm{Me}), 1.19$ (d, $\left.J_{\mathrm{Me}-\mathrm{H} 3}=6.8 \mathrm{~Hz}, 3 \mathrm{H}, \mathrm{C} 3-\mathrm{Me}\right) .{ }^{13} \mathrm{C}(75 \mathrm{MHz}): 111.6,109.5$, 104.9, 83.5, 82.7, 77.6, 67.2, 42.4, 26.8, 26.5, 26.3, 25.2, 10.1.

Compound 8. ${ }^{1} \mathrm{H}(300 \mathrm{MHz})$, major epimer: $5.77\left(\mathrm{~d}, J_{12}=3.6 \mathrm{~Hz}\right.$, $1 \mathrm{H}, \mathrm{H} 1), 4.56$ (t, $J=4.2 \mathrm{~Hz}, 1 \mathrm{H}, \mathrm{H} 2), 3.87(\mathrm{dd}, J=4.2,10.1 \mathrm{~Hz}, 1 \mathrm{H})$, 3.81-3.71 (unresolved, $2 \mathrm{H}$ ), 2.71 and 2.50 (two br s, exchangeable, $-\mathrm{OH}$ ), 2.04 (ddq, $J_{32}=4.6 \mathrm{~Hz}, J_{\mathrm{H} 3-\mathrm{Me}}=6.6 \mathrm{~Hz}, J_{34}=10.7 \mathrm{~Hz}, 1 \mathrm{H}, \mathrm{H} 3$ ), 1.52 and 1.33 (two s, 3H each, isopropylidene Me), 1.15 (d, $J_{\mathrm{Me}-\mathrm{H} 3=}$ $6.8 \mathrm{~Hz}, 3 \mathrm{H}, \mathrm{C} 3 \mathrm{Me}) .{ }^{13} \mathrm{C}(75 \mathrm{MHz}): 11.7,104.6,83.8,83.4,72.6,63.3$, $40.3,26.7,26.3,10.0$. HRMS (electrospray) calcd for $\mathrm{C}_{10} \mathrm{H}_{18} \mathrm{O}_{5}+\mathrm{Na}^{+}$: 241.10521, found: 241.10432 .

\subsection{3-Deoxy-1,2-O-isopropylidene-3-C-methyl-D-ribo- furanose 10}

To a magnetically stirred solution of the allo epimer $7(0.72 \mathrm{~g}$, $2.8 \mathrm{mmol})$ in dry EtOAc $(15 \mathrm{ml})$ was added $\mathrm{H}_{5} \mathrm{IO}_{6}(0.76 \mathrm{~g}, 3.4 \mathrm{mmol})$. The mixture turned opaque within several seconds. Stirring was continued for $1 \mathrm{~h} 45 \mathrm{~min}$. TLC in 18:3 hexane-EtOAc showed that all substrate with $R_{f} 0.40$ reacted to form the aldehyde 9 with $R_{f} 0.18$. The mixture was filtered through a sintered glass and nearly all solvent was evaporated. Small quantity of solid material appeared. $\mathrm{Et}_{2} \mathrm{O}$ was added and the mixture was passed through a bed of Celite. The volatiles were evaporated. The residue was solubilized in technical grade EtOH $(20 \mathrm{ml})$ and $\mathrm{NaBH}_{4}(0.07 \mathrm{~g}, 1.9 \mathrm{mmol})$ was added in one portion while maintaining magnetic stirring. After $2 \mathrm{~h}$, TLC showed a new more polar alcohol 10 with $R_{f}$ 0.51 in 20:0.5 $\mathrm{CH}_{2} \mathrm{Cl}_{2}-\mathrm{MeOH}$. Evaporation and flash chromatography in 20:0.4 $\mathrm{CH}_{2} \mathrm{Cl}_{2}-\mathrm{MeOH}$ gave $10(0.32 \mathrm{~g}, 61 \%)$.

${ }^{1} \mathrm{H}(300 \mathrm{MHz}): 5.80$ (d, $\left.J_{12}=3.6 \mathrm{~Hz}, 1 \mathrm{H}, \mathrm{H} 1\right), 4.58(\mathrm{t}, J=4.1 \mathrm{~Hz}, 1 \mathrm{H}$, $\mathrm{H} 2$ ), 3.92-3.81 (three groups of multiplets, 2H), 3.55 (ddd, $J_{5^{\prime \prime}} 4=3.6 \mathrm{~Hz}, \mathrm{~J}^{\prime \prime}-\mathrm{OH}=7.4 \mathrm{~Hz}, J_{5^{\prime \prime} 5^{\prime}}=12.0 \mathrm{~Hz}, 1 \mathrm{H}, \mathrm{H}^{\prime \prime}$ ), 2.29 (dd, JOH-5'= $4.9 \mathrm{~Hz}, \quad J_{\mathrm{OH}-5^{\prime \prime}}=7.8 \mathrm{~Hz}, \quad 1 \mathrm{H}$, exchangeable, $-\mathrm{OH}$ ), 2.07 (ddq, $J_{32}=4.7 \mathrm{~Hz}, J_{3}-\mathrm{Me}=6.8 \mathrm{~Hz}, J_{34}=10.2 \mathrm{~Hz}, 1 \mathrm{H}, \mathrm{H3}$ ), 1.51 and 1.34 (two s, $3 \mathrm{H}$ each, isopropylidene Me), 1.07 (d, JMe-3 $=6.8 \mathrm{~Hz}, 3 \mathrm{H}, \mathrm{C} 3-\mathrm{Me}) .{ }^{13} \mathrm{C}$ (75 MHz): 111.5, 104.8, 83.1, 83.0, 61.3, 38.0, 26.6, 26.2, 9.1. HRMS (electrospray) calcd for $\mathrm{C}_{9} \mathrm{H}_{16} \mathrm{O}_{4}+\mathrm{Na}^{+}: 211.09410$, found: 211.09376 .

\subsection{3-Deoxy-1,2-isopropylidene-3C-methyl-5-O-tosyl-D- ribo-furanose 11}

\subsubsection{From D-ribo alcohol $\mathbf{1 0}$}

Compound $10(0.32 \mathrm{~g}, 1.7 \mathrm{mmol})$ was conventionally tosylated using $\mathrm{TsCl}(0.65 \mathrm{~g}, 3.4 \mathrm{mmol})$ in $\mathrm{CH}_{2} \mathrm{Cl}_{2}(20 \mathrm{ml})$, pyridine $(1 \mathrm{ml})$, and cat. DMAP overnight. Few drops of water were added to destroy the excess of $\mathrm{TsCl}$ for $1 \mathrm{~h}$. Partition between $\mathrm{CH}_{2} \mathrm{Cl}_{2}$ and dil $\mathrm{HCl}$, washing the organic phase with water, drying, evaporation, and crystallization from EtOAc gave $\mathbf{1 1}(0.45 \mathrm{~g}, 75 \%)$ with $R_{f} 0.26$ in $4: 1$ hexaneEtOAc.

\subsubsection{From a mixture of $\mathbf{6}$ and $\mathbf{7}$ obtained by hydrogenation of $\mathbf{5}$ over Adam's catalyst via epimeric alcohols 12}

To a cold (ice bath) magnetically stirred solution of $\mathbf{6}$ and $\mathbf{7}$ ( $7.3 \mathrm{~g}, 28.3 \mathrm{mmol}$ ) in dry EtOAc was added $\mathrm{H}_{5} \mathrm{IO}_{6}(8.4 \mathrm{~g}, 36.8 \mathrm{mmol})$ in one portion under the atmosphere of nitrogen. The cooling bath was removed. After $2.5 \mathrm{~h}$, the mixture was worked-up as described for 9 to furnish yellowish oil. This oil was solubilized in $80 \mathrm{ml}$ of $96 \%$ EtOH, cooled in ice bath, and treated with $\mathrm{NaBH}_{4}(1.0 \mathrm{~g}, 28.3 \mathrm{mmol})$ added portionwise while maintaining magnetic stirring; $30 \mathrm{~min}$ later dil acetic acid was added to neutrality (indicator paper) and the volatiles were evaporated. The residue was solubilized in EtOAc and the resulting opaque solution was washed with water. The organic phase was dried, filtered, evaporated, and finally dried on an oil pump to furnish epimeric alcohols 12. Dry $\mathrm{CH}_{2} \mathrm{Cl}_{2}$ was added followed by pyridine $(7.5 \mathrm{ml})$, cat. quantity of DMAP, and $\mathrm{TsCl}$ (10.1 g, $53.2 \mathrm{mmol}$ ). After an overnight reaction, TLC showed a single spot of the products $\left(R_{f} 0.26\right.$ in $4: 1$ hexane-EtOAc) and a fast moving spot of TsCl. Extraction was performed as described above. $\mathrm{TsCl}$ still present was removed by flash chromatography in hexaneEtOAc, gradient $4: 1 \rightarrow 3: 1$, and the epimeric tosylates were crystallized from EtOAc at rt overnight to furnish a pure ribo epimer 11 $(5.22 \mathrm{~g}, 54 \%)$ together with $2.55 \mathrm{~g}$ of the mixture of the ribo/xylo tosylates.

Mp $120-123{ }^{\circ} \mathrm{C}$ (EtOAc), $[\alpha]_{\mathrm{D}}^{24}+22.1\left(\right.$ c $\left.6, \mathrm{CHCl}_{3}\right) .{ }^{1} \mathrm{H}(300 \mathrm{MHz})$ : 7.80 (d, $J=8.2 \mathrm{~Hz}, 2 \mathrm{H}, \mathrm{H}$ aromatic), 7.34 (d, $J=8.2 \mathrm{~Hz}, 2 \mathrm{H}, \mathrm{H}$ aromatic), 5.68 (d, $J_{12}=3.5 \mathrm{~Hz}, 1 \mathrm{H}, \mathrm{H} 1$ ), 4.52 (t, $\left.J=4.1 \mathrm{~Hz}, 1 \mathrm{H}, \mathrm{H} 2\right), 4.23$ (dd, $\left.J_{5^{\prime} 4}=2.5 \mathrm{~Hz}, J_{5^{\prime} 5^{\prime \prime}}=11.1 \mathrm{~Hz}, 1 \mathrm{H}, \mathrm{H} 5\right), 4.07$ (dd, $J_{5^{\prime \prime}} 4=3.9 \mathrm{~Hz}$, $J_{5^{\prime \prime} 5^{\prime}}=11.1 \mathrm{~Hz}, 1 \mathrm{H}, \mathrm{H} 5^{\prime \prime}$ ), $3.86\left(\mathrm{dt}, J_{45^{\prime}}=J_{45^{\prime \prime}}=3.2 \mathrm{~Hz}, J_{43}=10.3 \mathrm{~Hz}, 1 \mathrm{H}\right.$, $\mathrm{H} 4$ ), 2.44 (s, 3H, Me), 2.02 (ddq, $J_{32}=4.5 \mathrm{~Hz}, J_{3}-\mathrm{Me}=7.5 \mathrm{~Hz}, J_{34}=10.0 \mathrm{H}$, $1 \mathrm{H}, \mathrm{H} 3$ ), 1.46 and 1.31 (two s, $3 \mathrm{H}$ each, isopropylidene Me), 1.03 (d, $\left.J_{\mathrm{Me}-\mathrm{H} 3}=6.8 \mathrm{~Hz}, 3 \mathrm{H}, \mathrm{C} 3-\mathrm{Me}\right) .{ }^{13} \mathrm{C}(75 \mathrm{MHz}): 144.9,132.8,129.8$, 128.0, 111.7, 104.8, 82.5, 79.9, 68.5, 39.2, 29.7, 26.3, 21.6, 9.0. HRMS (electrospray) calcd for $\mathrm{C}_{16} \mathrm{H}_{22} \mathrm{O}_{6} \mathrm{~S}+\mathrm{H}^{+}:$343.12099, found: 343.12031.

\subsection{3,5-Dideoxy-3-C-methyl-D-ribo-furanose 15}

To a solution of the tosylate $\mathbf{1 1}(2.9 \mathrm{~g}, 8.4 \mathrm{mmol})$ in THF $(20 \mathrm{ml})$ under nitrogen was injected $1 \mathrm{M} \mathrm{LiBH}(\mathrm{Et})_{3}(15 \mathrm{ml})$ at $\mathrm{rt}$ and the mixture was left overnight. TLC showed that all $\mathbf{1 1}$ with $R_{f} 0.26$ disappeared to form a faint, weakly charring spot of 13 with $R_{f} 0.65$ in $4: 1$ hexane-EtOAc. $\mathrm{H}_{2} \mathrm{SO}_{4}(1 \mathrm{M}, 30 \mathrm{ml})$ was cautiously added (1.5 $\mathrm{M} \mathrm{H}_{2} \mathrm{SO}_{4}$ could also be used). Two layers were formed. Small volume of technical grade THF $(\sim 10 \mathrm{ml})$ was added to achieve homogeneity. Slightly opaque solution was magnetically stirred overnight. TLC showed that the product having a putative structure 14 was less polar than the acetonide 13. The mixture was transferred to a separatory funnel charged with $\mathrm{CH}_{2} \mathrm{Cl}_{2}$-water and exhaustive extraction $(3 \times)$ was performed. The organic phase was washed once with water. Combined water phases were extracted with EtOAc $(3 \times)$ and the combined organic phases were washed with water. To the $\mathrm{CH}_{2} \mathrm{Cl}_{2}$ phase was added methanol $(200 \mathrm{ml})$ and the volatiles were evaporated. To the residue, $\mathrm{MeOH}$ was added again $(300 \mathrm{ml})$ and was subsequently evaporated. This was repeated two more times. The EtOAc layer was treated in the same manner. TLC of the combined residues showed that $\mathbf{1 4}$ was no longer present. The newly formed diol 15 showed $R_{f} 0.38$ in 20:1.3 $\mathrm{CH}_{2} \mathrm{Cl}_{2}-\mathrm{MeOH}$. Flash chromatography in this system furnished $\mathbf{1 5}$, $0.82 \mathrm{~g}$ as an oil in $73 \%$ cumulative yield counted on a tosylate $\mathbf{1 1}$. Diol 15 chars more intensely while using $2 \% \mathrm{CrO}_{3}$ in $10 \% \mathrm{aq}_{2} \mathrm{SO}_{4}$ than using $10 \% \mathrm{H}_{2} \mathrm{SO}_{4}$ in $\mathrm{MeOH}$. In another run yield of 15 was $54 \%$.

$[\alpha]_{\mathrm{D}}^{24}+27.9$ (c 5.7, $\mathrm{CHCl}_{3}$, after $\left.30 \mathrm{~min}\right) .{ }^{1} \mathrm{H}(500 \mathrm{MHz}): 5.383$ (d, $J_{12}=3.8 \mathrm{~Hz}, \mathrm{H} 1$ ), 5.191 (s, H1), 5.11 (br s, exchangeable, $-\mathrm{OH}$ ), 4.038 (t, $J=4.5 \mathrm{~Hz}, \mathrm{H} 2$ ), 3.943 (d, $\left.J_{23}=4.3 \mathrm{~Hz}, \mathrm{H} 2\right), 3.891$ (dq, $J_{4-\mathrm{Me}}=6.0 \mathrm{~Hz}$, $\left.J_{43}=10.2 \mathrm{~Hz}, \mathrm{H} 4\right), 3.859$ (dq, $J_{4-\mathrm{Me}}=6.1 \mathrm{~Hz}, J_{43}=10.3 \mathrm{~Hz}$ ), 3.70 and 3.28 (two br s, exchangeable, $-\mathrm{OH}$ ), 2.006 ( $\mathrm{m}$ of 14 lines, $J_{3-\mathrm{Me}}=6.9 \mathrm{~Hz}, J_{34}=\sim 9.6 \mathrm{~Hz}, J_{32}=4.3 \mathrm{~Hz}, \mathrm{H} 3$ ), 1.705 (m of 14 lines, $\left.J_{3-\mathrm{Me}}=6.6 \mathrm{~Hz}, J_{34}=9.6 \mathrm{~Hz}, J_{32}=\sim 5.5 \mathrm{~Hz}, \mathrm{H} 3\right), 1.277\left(\mathrm{~d}, J_{\mathrm{Me}-\mathrm{H} 4}=6.2 \mathrm{~Hz}\right.$, terminal Me), $1.183\left(\mathrm{~d}, J_{\mathrm{Me}-\mathrm{H} 4}=6.1 \mathrm{~Hz}\right), 1.001\left(\mathrm{~d}, J_{\mathrm{Me}-\mathrm{H} 2}=7.0 \mathrm{~Hz}, \mathrm{C} 2-\right.$ $\mathrm{Me}), 0.995$ (d, $\left.J_{\mathrm{Me}-\mathrm{H} 2}=6.9 \mathrm{~Hz}, \mathrm{C} 2-\mathrm{Me}\right) .{ }^{13} \mathrm{C}(75 \mathrm{MHz}): 102.29,97.13$, 80.91, 78.81, 78.51, 73.58, 44.84, 42.28, 20.68, 18.82, 9.73, 9.16. HRMS (EI) calcd for $\mathrm{C}_{6} \mathrm{H}_{12} \mathrm{O}_{3}-\mathrm{OH}$ : 115.07589 , found: 115.07717 .

\subsection{2-Naphthylmethyl (3R)-formyloxy-(2R)-methylbutanoate 19 and 2-napthylmethyl (3R)-hydroxy-(2R)-methylbutanoate 20}

\subsubsection{Procedure $A$}

To a magnetically stirred solution of the diol $15(011 \mathrm{~g}$, $0.83 \mathrm{mmol})$ in $\mathrm{EtOH}(8 \mathrm{ml})$ was added $\mathrm{NaIO}_{4}(0.21 \mathrm{~g}, 1 \mathrm{mmol})$, 
solubilized in minimum volume of distd $\mathrm{H}_{2} \mathrm{O}(\sim 2 \mathrm{ml})$. The mixture became opaque immediately. After $1.5 \mathrm{~h}$, TLC showed a high migrating very weakly charring spot $\left(R_{f} 0.87\right.$ in 20:1 $\mathrm{CH}_{2} \mathrm{Cl}_{2}-\mathrm{MeOH}$ ) and a small amount of unreacted 15. Few milligrams of solid $\mathrm{NaIO}_{4}$ were added to complete the diol cleavage. The mixture was filtered through sintered glass and evaporated at ca. $20^{\circ} \mathrm{C}$. Addition of $\mathrm{CH}_{3} \mathrm{CN}(8 \mathrm{ml})$ precipitated some more white solid. Filtration and evaporation were repeated. To the residue solubilized in $\mathrm{CH}_{3} \mathrm{CN}(25 \mathrm{ml})$ was added $\mathrm{NaClO}_{2}(80 \%$ pure, $0.26 \mathrm{~g}, 2.21 \mathrm{mmol}$ ) in minimum volume of distd water, followed by $0.2 \mathrm{ml}$ of $35 \% \mathrm{H}_{2} \mathrm{O}_{2}$ and $\mathrm{NaH}_{2} \mathrm{PO}_{4} \cdot 2 \mathrm{H}_{2} \mathrm{O}(0.066 \mathrm{~g}$, $0.42 \mathrm{mmol}$ ) in minimum volume of distd water. The additions were done in this order. The mixture was stirred for $2 \mathrm{~h}$. TLC run in 20:1 $\mathrm{CH}_{2} \mathrm{Cl}_{2}$ and revealed in bromocresol green reagent showed two yellow elongated spots on a blue background: the upper more intense one belonging to the $O$-formylated acid $\mathbf{1 7}$ and the more polar spot belonging to the hydroxy acid $\mathbf{1 8}$. The reaction mixture was filtered through Celite and the volatiles were evaporated and dried on an oil pump. The residual oil was solubilized in $\mathrm{CH}_{2} \mathrm{Cl}_{2}(20 \mathrm{ml})$ and a freshly prepared solution of 2-naphthyldiazomethane $\mathbf{2 3}$ was added using a Pasteur pipette. Addition of $\mathbf{2 3}$ was continued until reddish color persisted and evolution of nitrogen ceased. TLC at this point showed the presence of strongly UV absorbing spots of 19 with $R_{f} 0.65$ and 20 with $R_{f} 0.30$ in 4:1 hexane-EtOAc. Several other UV absorbing spots were present presumably arising from the decomposition of 23. Upon spraying with a $\mathrm{CrO}_{3}-\mathrm{H}_{2} \mathrm{SO}_{4}$ system and heating at $120-130{ }^{\circ} \mathrm{C}$ both 19 and 20 form reddish-brown spots. Evaporation of the solvent and flash chromatography using a gradient of EtOAc in hexane, $1: 19 \rightarrow 1: 3$, furnished $19(0.10 \mathrm{~g}, 42 \%)$ and 20 $(0.081 \mathrm{~g}, 37 \%)$.

3.7.2. Procedure B: 2-naphthylmethyl (3R)-hydroxy-(2R)-methylbutanoate 20 from 2-naphthylmethyl (3R)-formyloxy-(2R)-methylbutanoate 19

To a solution of the formate $\mathbf{1 9}$ in $\mathrm{MeOH}(6 \mathrm{ml})$ was added one drop of concd $\mathrm{NH}_{4} \mathrm{OH}$. After $1 \mathrm{~h}$, TLC showed a complete conversion of $\mathbf{1 9}$ to a more polar $\mathbf{2 0}$ (system as above). Evaporation and flash chromatography furnished 20 (0.080 g, 89\%).

\subsubsection{Procedure C: 2-naphthylmethyl (3R)-hydroxy-(2R)-methyl-} butanoate $\mathbf{2 0}$ from a mixture of $\mathbf{1 9}$ and $\mathbf{2 0}$ without chromatographic separation as in procedure $A$

Isolation of the formate $\mathbf{1 9}$ can be skipped and a crude mixture after the esterification with $\mathbf{2 3}$ can be subjected to ammonolysis. Thus, evaporation of $\mathrm{CH}_{2} \mathrm{Cl}_{2}$, solubilization in $\mathrm{MeOH}(10 \mathrm{ml})$, and addition of few drops of concd $\mathrm{NH}_{4} \mathrm{OH}$ transformed 19 to 20 for $\sim 45 \mathrm{~min}$. Evaporation of the solvent and flash chromatography using a gradient of EtOAc in hexane, $1: 4 \rightarrow 1: 3$, furnished 20 in $\sim 70 \%$ yield counting on the diol 15 .

Compound 19. ${ }^{1} \mathrm{H}(300 \mathrm{MHz}): 7.90(\mathrm{~s}, 1 \mathrm{H}, \mathrm{CHO}), 7.84-7.81(\mathrm{~m}, 4 \mathrm{H}$, $\mathrm{H}$ aromatic), 7.50-7.43 (m, 3H, $\mathrm{H}$ aromatic), 5.29 (s, $\left.2 \mathrm{H},-\mathrm{OCH}_{2}-\right)$, 5.27 (quintette, $J=6.6 \mathrm{~Hz}, 1 \mathrm{H}, \mathrm{H} 3$ ), 2.80 (quintette, $J=7.2 \mathrm{~Hz}, 1 \mathrm{H}, \mathrm{H} 2$ ), 1.26 (d, $J=6.4 \mathrm{~Hz}, 3 \mathrm{H}$, terminal Me), 1.21 (d, $J=7.1 \mathrm{~Hz}, 3 \mathrm{H}, \mathrm{C} 2-\mathrm{Me}$ ). ${ }^{13} \mathrm{C}(75 \mathrm{MHz}): 173.3,160.2,133.2,133.1,128.4,128.0,127.7,127.5$, 126.4, 126.3, 125.9, 71.5, 66.6, 44.6, 17.0, 12.8. HRMS (electrospray) calcd for $\mathrm{C}_{17} \mathrm{H}_{18} \mathrm{O}_{4}+\mathrm{Na}^{+}$: 309.11029, found: 309.10968; calcd for $\mathrm{C}_{17} \mathrm{H}_{18} \mathrm{O}_{4}+\mathrm{K}^{+}: 325.08420$, found: 325.08357 .

Compound 20. $[\alpha]_{\mathrm{D}}^{24}-24.1\left(\right.$ c $\left.5, \mathrm{CHCl}_{3}\right) \cdot{ }^{1} \mathrm{H}(500 \mathrm{MHz}): 7.85-7.82$ (4H, $\mathrm{H}$ aromatic), 7.51-7.44 (3H, $\mathrm{H}$ aromatic), 5.32 (s, $2 \mathrm{H},-\mathrm{OCH}_{2}-$ ), 3.92 (quintette of broadened lines, $J=6.3 \mathrm{~Hz}, 1 \mathrm{H}, \mathrm{H} 3$ ), 2.64 (br s, exchangeable, $-\mathrm{OH}$ ), 2.54 (quintette, $J=7.2 \mathrm{~Hz}, 1 \mathrm{H}, \mathrm{H} 2$ ), 1.222 (d, $J=6.4 \mathrm{~Hz}, 3 \mathrm{H}$, terminal Me), $1.216(\mathrm{~d}, J=7.2 \mathrm{~Hz}, 3 \mathrm{H}, \mathrm{C} 2-\mathrm{Me}) .{ }^{13} \mathrm{C}$ (75 MHz): 175.7, 133.14, 133.09, 128.4, 128.0, 127.7, 127.3, 126.32, $126.29,125.7,69.4,66.5,47.1,20.7,14.1$. HRMS (electrospray) calcd for $\mathrm{C}_{16} \mathrm{H}_{18} \mathrm{O}_{3}+\mathrm{Na}^{+}: 281.11483$, found: 281.11465 .

\subsection{2-Naphthylmethyl hydrazone 22}

To a magnetically stirred solution of 2-naphthylcarbaldehyde $\mathbf{2 1}$ $(15.0 \mathrm{~g}, 96 \mathrm{mmol})$ in techn. EtOH $(70 \mathrm{ml})$ was added hydrazine hydrate $(100 \%, 9.6 \mathrm{~g}, 9.3 \mathrm{ml}, 188 \mathrm{mmol})$ via a syringe for $\sim 5 \mathrm{~min}$ with external cooling in ice bath. After the addition was complete, cooling bath was removed and semi-solid slurry was left overnight at rt. The semi-solid mixture was cooled, filtered on a sintered glass, and washed with an ice-cold 1:1 EtOH-Et ${ }_{2} \mathrm{O}$ and finally with icecold $\mathrm{Et}_{2} \mathrm{O}$. Final drying on an oil pump gave the crude hydrazone 22 (15.0 g, 92\%). Mp 148-151 ${ }^{\circ} \mathrm{C}$ (EtOH), lit. ${ }^{36} 149-150{ }^{\circ} \mathrm{C}$.

${ }^{1} \mathrm{H}\left(300 \mathrm{MHz}, \mathrm{CDCl}_{3}+\mathrm{a}\right.$ drop of DMSO- $\left.\mathrm{d}_{6}\right): 7.88-7.76(\mathrm{~m}, 6 \mathrm{H})$, 7.51-7.41 (m, 2H), 5.9 (br s, exchangeable, $\left.-\mathrm{NH}_{2}\right) .{ }^{13} \mathrm{C}(75 \mathrm{MHz})$ : 141.3, 132.7, 132.6, 125.68, 125.52, 125.46, 122.2. HRMS (electrospray) calcd for $\mathrm{C}_{11} \mathrm{H}_{10} \mathrm{~N}_{2}+\mathrm{H}^{+}$: 171.09167, found: 172.09165 .

\subsection{2-Naphthylmethyldiazomethane 23}

A mixture of the hydrazone $22(1.08 \mathrm{~g}, 6.4 \mathrm{mmol})$ in $\mathrm{CH}_{2} \mathrm{Cl}_{2}$ ( $40 \mathrm{ml})$, yellow $\mathrm{HgO}(1.96 \mathrm{~g}, 9.0 \mathrm{mmol})$, and a small crushed pellet of $\mathrm{KOH}$ was magnetically stirred for $3 \mathrm{~h}$. The initial bright yelloworange color of the heterogeneous mixture gradually faded and a gray deposit of mercury appeared. Stirring was stopped and after sedimentation of the solids the orange-red solution of $\mathbf{2 3}$ was pipetted for the esterification step. This solution was always freshly prepared. Although we have never experienced any problem with this preparation, it should be remembered that any diazo compound is potentially unstable.

\subsection{1,2-O-Isopropylidene-L-xylo-furanose 24}

L-Xylose ( $20 \mathrm{~g}, 134 \mathrm{mmol}$ ) in $520 \mathrm{ml}$ of dry acetone and $20 \mathrm{ml}$ of concd $\mathrm{H}_{2} \mathrm{SO}_{4}$ were stirred magnetically for $50 \mathrm{~min}$. The flask was cooled in ice-water bath and a solution of $26 \mathrm{~g}, 246 \mathrm{mmol}$ of anhyd $\mathrm{Na}_{2} \mathrm{CO}_{3}$ in $225 \mathrm{ml}$ of water was gradually added to keep the internal temperature below $20^{\circ} \mathrm{C}$ and to avoid excessive frothing; $2.5 \mathrm{~h}$ after the end of addition, solid anhyd $\mathrm{Na}_{2} \mathrm{CO}_{3}(14 \mathrm{~g}, 132 \mathrm{mmol})$ was added for 15 min to neutralize all $\mathrm{H}_{2} \mathrm{SO}_{4}$. Stirring was continued for $10 \mathrm{~min}$ more. TLC showed a spot with $R_{f} 0.45\left(\mathrm{CH}_{2} \mathrm{Cl}_{2}-\mathrm{MeOH}\right)$. The solids were filtered and acetone was evaporated. The residual oil was purified by flash chromatography in $\mathrm{CH}_{2} \mathrm{Cl}_{2}-\mathrm{MeOH}, 30: 1 \rightarrow 20: 1$, to furnish 24 (19.0 g, 75\%) as a syrup, which solidified upon storage in a refrigerator. An alternative one-pot preparation described for L-xylose is much longer and was considered less convenient. ${ }^{46}$

$[\alpha]_{\mathrm{D}}^{24}+18.2\left(\mathrm{c} \mathrm{3.4}, \mathrm{CHCl}_{3}\right)$, commercial $\mathrm{D}$-form from the Aldrich has $[\alpha]_{\mathrm{D}}^{24}-19.2\left(c \mathrm{1}, \mathrm{H}_{2} \mathrm{O}\right) .{ }^{1} \mathrm{H}(300 \mathrm{MHz}): 5.99\left(\mathrm{~d}, J_{12}=3.6 \mathrm{~Hz}, 1 \mathrm{H}\right.$, $\mathrm{H} 1), 4.53$ (d, $\left.J_{21}=3.6 \mathrm{~Hz}, 1 \mathrm{H}, \mathrm{H} 2\right), 4.33$ (br s, $\left.1 \mathrm{H}\right), 4.19-4.02(\mathrm{~m}, 4 \mathrm{H}$, one proton exchangeable), 1.49 and 1.33 (two s, 3H each, isopropylidene Me). ${ }^{13} \mathrm{C}(75 \mathrm{MHz}): 111.8,104.8,85.6,78.6,76.9,61.1$, 26.7, 26.1. HRMS (electrospray) calcd for $\mathrm{C}_{8} \mathrm{H}_{14} \mathrm{O}_{5}+\mathrm{Na}^{+}:$213.07736, found: 213.07320 .

\subsection{5-O-tert-Butyldimethylsilyl-1,2-0-isopropylidene-L- xylo-furanose 25}

To a solution of the diol $2418.5 \mathrm{~g}, 97.4 \mathrm{mmol}$ in dry DMF (Aldrich, sold with molecular sieves) $100 \mathrm{ml}$ under a blanket of nitrogen, was added imidazole $16.5 \mathrm{~g}, 240 \mathrm{mmol}$ and tert-butyldimethylsilyl chloride $14.8 \mathrm{~g}, 110 \mathrm{mmol}$. After an overnight reaction, TLC showed one spot with $R_{f} 0.45$ in 4:1 hexane-EtOAc. Conventional extraction and flash chromatography in hexane-EtOAc, $17: 3 \rightarrow 4: 1$, furnished $22 \mathrm{~g}, 75 \%$ of $\mathbf{2 5}$.

$[\alpha]_{\mathrm{D}}^{24}+11.0\left(\right.$ c $\left.5.4, \mathrm{CHCl}_{3}\right) .{ }^{1} \mathrm{H}(300 \mathrm{MHz}): 5.96\left(\mathrm{~d}, J_{12}=3.6 \mathrm{~Hz}, 1 \mathrm{H}\right.$, $\mathrm{H} 1), 4.51\left(\mathrm{~d}, J_{21}=3.6 \mathrm{~Hz}, 1 \mathrm{H}, \mathrm{H} 2\right), 4.38(\mathrm{~d}, J=2.7 \mathrm{~Hz}, 1 \mathrm{H}$ ), 3.37 (apparent $\mathrm{t}, J=2.5 \mathrm{~Hz}, 2 \mathrm{H}$, one $\mathrm{H}$ exchangeable), 4.15-4.08 (unresolved, $2 \mathrm{H}, \mathrm{H} 5$ ), 1.48 and 1.32 (two s, $3 \mathrm{H}$ each, isopropylidene $\mathrm{Me}$ ), 0.89 (s, 
9H, $\left.{ }^{t} \mathrm{Bu}\right), 0.11$ (s, 6H, Me $\left.2 \mathrm{Si}\right) .{ }^{13} \mathrm{C}(75 \mathrm{MHz}): 111.5,105.0,85.6,78.1$, 77.1, 62.4, 26.8, 26.1, 25.7, 18.1, -5,5, -5.7. HRMS (electrospray) calcd for $\mathrm{C}_{14} \mathrm{H}_{28} \mathrm{O}_{5} \mathrm{Si}+\mathrm{H}^{+}$: 305.17786 , found: 305.17726 .

\subsection{5-O-tert-Butyldimethylsilyl-3-deoxy-1,2-0- isopropylidene-3-C-methylene-L-erythro-pentofuranose 26}

A complex of $\mathrm{CrO}_{3}$. Py was prepared by the addition of pyridine $(16.9 \mathrm{ml}, 209 \mathrm{mmol})$ to $\mathrm{CrO}_{3}(10.4 \mathrm{~g}, 104 \mathrm{mmol})$ in dry $\mathrm{CH}_{2} \mathrm{Cl}_{2}$ $(200 \mathrm{ml})$ under nitrogen while maintaining stirring for $30 \mathrm{~min}$. To this dark brown solution was added 25 ( $10.0 \mathrm{~g}, 32.9 \mathrm{mmol})$ in $40 \mathrm{ml}$ of dry $\mathrm{CH}_{2} \mathrm{Cl}_{2}$ immediately followed by $\mathrm{Ac}_{2} \mathrm{O}(10.2 \mathrm{ml}, 108 \mathrm{mmol})$. The mixture became warm. TLC (hexane-EtOAc 17:3) showed a conversion of $\mathbf{2 5}$ into a slightly less polar product. After $10 \mathrm{~min}$, the excess of chromium compounds was precipitated by the addition of $240 \mathrm{ml}$ of 1:1 EtOAc and toluene mixture. Black solids were washed twice with 1:1 EtOAc-toluene. The original supernatant and the washings were applied on top of a silica gel (70-200 mesh) column prepared in 2:1 EtOAc-toluene. Slight overpressure was used to push the solution through the gel. Elution with 2:1 EtOActoluene was performed. The fractions containing the product were pooled together, evaporated, and co-evaporated with xylenes. Final drying was performed on an oil pump.

To a suspension of $\mathrm{Ph}_{3} \mathrm{P}^{+} \mathrm{Me}\left(\mathrm{Br}^{-}\right)(98 \%, 17.5 \mathrm{~g}, 48 \mathrm{mmol})$ in $600 \mathrm{ml}$ of THF cooled with EtOH-dry ice was injected $2.5 \mathrm{M}$ BuLi in hexane (18.2 ml, $45.5 \mathrm{mmol})$ with constant magnetic stirring. After the addition, cooling bath was removed for $50 \mathrm{~min}$ and re-applied again. A solution of the abovementioned oxidation product in $100 \mathrm{ml}$ of THF was added via a syringe and the mixture was left to reach rt overnight. TLC showed a complete conversion of the substrate with $R_{f} 0.44$ into a strongly charring spot of the olefin 25 with $R_{f} 0.80$ in 17:3 hexane-EtOAc. The solids were filtered on a sintered glass and THF was evaporated. The resulting yellow oil was solubilized in $\mathrm{CH}_{2} \mathrm{Cl}_{2}$ and washed with water. The extract was dried and evaporated, and the residue was purified by flash chromatography in 19:1 hexane-EtOAc to furnish $\mathbf{2 6}(6.9 \mathrm{~g}, 70 \%)$ as an oil for two steps.

$[\alpha]_{\mathrm{D}}^{24}-127.6\left(c 3.9, \mathrm{CHCl}_{3}\right) .{ }^{1} \mathrm{H}(300 \mathrm{MHz}): 5.85\left(\mathrm{~d}, J_{12}=4.1 \mathrm{~Hz}, 1 \mathrm{H}\right.$, H1), 5.42 (dd, $J=1.2,2.2 \mathrm{~Hz}, 1 \mathrm{H}), 5.27$ (t, $J=1.7 \mathrm{~Hz}, 1 \mathrm{H}), 4.91-4.87$ (m, $1 \mathrm{H}), 4.78-4.74(\mathrm{~m}, 1 \mathrm{H}), 3.76\left(\mathrm{dd}, J_{5^{\prime}} 4=4.1 \mathrm{~Hz}, J_{5^{\prime} 5^{\prime \prime}}=10.6 \mathrm{~Hz}, 1 \mathrm{H}, \mathrm{H} 5^{\prime}\right)$, $3.68\left(\mathrm{dd}, J_{5^{\prime \prime} 4}=3.8 \mathrm{~Hz}, J_{5^{\prime \prime} 5^{\prime}}=10.6 \mathrm{~Hz}, 1 \mathrm{H}, \mathrm{H}^{\prime \prime}\right), 1.50$ and 1.39 (two s, $3 \mathrm{H}$ each, isopropylidene $\mathrm{Me}$ ), 0.88 ( $\mathrm{s}, 9 \mathrm{H},{ }^{t} \mathrm{Bu}$ ), 0.06 and 0.05 (two s, $\left.6 \mathrm{H}, \mathrm{Me}_{2} \mathrm{Si}\right) .{ }^{13} \mathrm{C}(75 \mathrm{MHz}): 147.6,112.5,111.5,104.9,81.99,81.96$, $80.8,65.6,27.5,27.3,25.8,18.2,-5.4,-5.5$. HRMS (electrospray) calcd for $\mathrm{C}_{15} \mathrm{H}_{28} \mathrm{O}_{4} \mathrm{Si}+\mathrm{H}^{+}: 301.18295$, found: 301.18239 .

\subsection{3-Deoxy-1,2-O-isopropylidene-3-C-methylene-L-erythro- pentofuranose 27}

The silane 26 (6.2 g, $20.7 \mathrm{mmol}$ ) in technical grade THF (30 ml) was deprotected with $1 \mathrm{M} \mathrm{Bu}_{4} \mathrm{NF}-\mathrm{THF}(22 \mathrm{ml})$ overnight. $R_{f}$ of the product is 0.43 in 1:1 hexane-EtOAc. Evaporation of THF and flash chromatography in the same system furnished $3.8 \mathrm{~g}$, quantitative yield, of 27.

$[\alpha]_{\mathrm{D}}^{24}-183.7\left(c 2.8, \mathrm{CHCl}_{3}\right) .{ }^{1} \mathrm{H}(300 \mathrm{MHz}): 5.87\left(\mathrm{~d}, J_{12}=4.0 \mathrm{~Hz}, 1 \mathrm{H}\right.$, H1), 5.48 (dd, $J=0.9,2.3 \mathrm{~Hz}, 1 \mathrm{H}$ ), 5.19 (dd, $J=1.2,2.1 \mathrm{~Hz}, 1 \mathrm{H}$ ), $4.93-4.91$ $(\mathrm{m}, 1 \mathrm{H}), 4.85-4.80(\mathrm{~m}, 1 \mathrm{H}), 3.88\left(\mathrm{~d}, J_{5^{\prime} 5^{\prime \prime}}=11.9 \mathrm{~Hz}, 1 \mathrm{H}, \mathrm{H} 5^{\prime}\right), 3.67(\mathrm{dd}$, $J_{5^{\prime \prime}}=4.4 \mathrm{~Hz}, J_{5^{\prime \prime} 5^{\prime}}=12.0 \mathrm{~Hz}, 1 \mathrm{H}, \mathrm{H} 5^{\prime \prime}$ ), 2.16 (br s, exchangeable, $1 \mathrm{H}$, $-\mathrm{OH}$ ), 1.52 and 1.39 (two $\mathrm{s}, 3 \mathrm{H}$ each, isopropylidene $\mathrm{Me}$ ). ${ }^{13} \mathrm{C}$ (75 MHz): 145.5, 112.6, 112.2, 104.4, 82.0, 80.0, 63.4, 21.4, 27.1. HRMS (electrospray) calcd for $\mathrm{C}_{9} \mathrm{H}_{14} \mathrm{O}_{4}+\mathrm{Na}^{+}$: 209.07845, found: 209.07818 .

3.14. 3-Deoxy-1,2-O-isopropylidene-3-C-methyl-t-ribofuranose 28 and 3-deoxy-1,2-O-isopropylidene-3-C-methyl-Lxylo-furanose 29

Hydrogenation of the olefin $27(3.6 \mathrm{~g}, 19.3 \mathrm{mmol})$ in $96 \% \mathrm{EtOH}$ $(22 \mathrm{ml})$ and $\mathrm{PtO}_{2} \cdot \mathrm{H}_{2} \mathrm{O}(0.102 \mathrm{~g})$ at the initial pressure of $45 \mathrm{psi}$ was performed in a Parr apparatus for $2.5 \mathrm{~h}$. Filtration of Pt (attention: pyrophoric) on the bed of Celite, evaporation, and drying furnished $3.6 \mathrm{~g}$, approximately quantitative yield, of both epimeric 3-Cmethyl products 28 and 29 in $\sim 10: 1$ proportion, which are inseparable under the flash chromatography conditions.

${ }^{13} \mathrm{C}(75 \mathrm{MHz}): 111.6,111.5,104.9,104.5,86.8,83.1,80.2$, 62.1, 40.5, 26.7, 26.3, 26.1, 10.9. HRMS (electrospray): calcd for $\mathrm{C}_{9} \mathrm{H}_{16} \mathrm{O}_{4}+\mathrm{Na}^{+}=211.09410$, found: 211.09380 .

\subsection{3-Deoxy-1,2-O-isopropylidene-3-C-methyl-5-O-tosyl-L- ribo-furanose 30}

Tosylation of the $\mathbf{2 8}$ and $\mathbf{2 9}$ mixture and crystallization of the major C-3-methyl L-ribo epimer proceeded as described for the enantiomeric compound $\mathbf{1 1}$ derived from D-glucose. Compound $\mathbf{3 0}$ was obtained in $69 \%$ yield together with $26 \%$ of the mixture $3-C$ methyl-5-O-tosyl L-ribo/xylo compounds, inseparable under the conditions of flash chromatography.

Mp $119-122{ }^{\circ} \mathrm{C}\left(\right.$ EtOAc), $[\alpha]_{\mathrm{D}}^{24}-21.4\left(\right.$ c 7, $\left.\mathrm{CHCl}_{3}\right)$. For ${ }^{1} \mathrm{H}$ and ${ }^{13} \mathrm{C}$ NMR data see enantiomeric compound 11. HRMS (electrospray) calcd for $\mathrm{C}_{16} \mathrm{H}_{22} \mathrm{O}_{6} \mathrm{~S}+\mathrm{H}^{+}$: 343.12097 , found: 343.12054 .

\subsection{3,5-Dideoxy-3C-methyl-L-ribo-furanose 31}

Compound $\mathbf{3 0}$ was converted to $\mathbf{3 1}$ in $64 \%$ yield following the procedure described for the transformation of its D-ribo enantiomer 11 to obtain 15.

$[\alpha]_{\mathrm{D}}^{24}-26.0\left(c \mathrm{c} .8, \mathrm{CHCl}_{3}\right)$. For NMR data see compound 15. HRMS (EI) calcd for $\mathrm{C}_{6} \mathrm{H}_{12} \mathrm{O}_{3}-\mathrm{OH}$ : 115.07589 , found: 115.07611 .

\subsection{0 -Methyl 3,5-dideoxy-3-C-methyl- $\alpha$-L-ribo-furanoside 32}

An unexpected glycosylation took place during conversion of $\mathbf{3 0}$ to $\mathbf{3 1}$ in one case, evidently due to the presence of acid in the crude $\mathrm{CH}_{2} \mathrm{Cl}_{2}$ and EtOAc extracts. The residue after evaporation of both solvents was solubilized in $\mathrm{MeOH}$ and left overnight at $\mathrm{rt}$, and evaporation was reassumed next day to destroy any borates present. TLC $\left(\mathrm{CH}_{2} \mathrm{Cl}_{2}-\mathrm{MeOH} 20: 1.3\right)$ showed the presence of two compounds: 32 with $R_{f} 0.62$ and 31 with $R_{f} 0.41$. Flash chromatography in the same system furnished $32(0.43 \mathrm{~g}, 28 \%)$ and $31(0.30 \mathrm{~g} \mathrm{22 \% )}$. This unwanted glycosylation can be avoided by performing all evaporations and chromatography in 1 day.

${ }^{1} \mathrm{H}(500 \mathrm{MHz}): 4.74(\mathrm{~s}, 1 \mathrm{H}, \mathrm{H} 1), 3.97\left(\mathrm{~d}, J_{23}=3.9 \mathrm{~Hz}, 1 \mathrm{H}, \mathrm{H} 1\right), 3.90$ (dq, $\left.J_{4-\mathrm{Me}}=6.1 \mathrm{~Hz}, J_{43}=9.3 \mathrm{~Hz}, 1 \mathrm{H}, \mathrm{H} 4\right), 3.35$ (s, 3H, -OMe), 2.51 (br s, exchangeable, $-\mathrm{OH}$ ), $1.98\left(\mathrm{ddq}, J_{34}=9.3 \mathrm{~Hz}, J_{23}=3.8 \mathrm{~Hz}, J_{3}-\mathrm{Me}=7.0 \mathrm{~Hz}\right.$, $1 \mathrm{H}, \mathrm{H} 3), 1.28$ (d, $\left.J_{\mathrm{Me}-4}=6.1 \mathrm{~Hz}, 3 \mathrm{H}, \mathrm{C} 4-\mathrm{Me}\right), 1.04$ (d, $J_{\mathrm{Me}-4}=7.0 \mathrm{~Hz}, 3 \mathrm{H}$, C3-Me). ${ }^{13} \mathrm{C}$ (75 MHz): 108.9, 80.9, 80.7, 54.3, 42.7, 20.9, 9.3. HRMS (EI) calcd for $\mathrm{C}_{7} \mathrm{H}_{17} \mathrm{O}_{3}-\mathrm{CH}_{3}$ : 115.07590 , found: 115.07692 .

\subsection{2-Naphthylmethyl (3S)-hydroxy-(2S)-methyl- butanoate 33}

Transformation of the diol $\mathbf{3 1}$ to the target $\mathbf{3 3}$ was performed as described for the enantiomeric compound $\mathbf{1 5} \rightarrow \mathbf{2 0}$ in 58\% cumulative yield.

$[\alpha]_{\mathrm{D}}^{24}+24.0\left(\right.$ c $6.8, \mathrm{CHCl}_{3}$ ). For NMR data see compound 20. HRMS (electrospray) calcd for $\mathrm{C}_{16} \mathrm{H}_{18} \mathrm{O}_{3}+\mathrm{K}^{+}: 297.08874$, found: 297.08869.

\subsection{5-O-tert-Butyldiphenylsilyl-D-arabino-furanose 34}

D-Arabinose (30 g, $0.2 \mathrm{~mol}$ ) was solubilized in dry DMF (300 ml) with warming to ca. $100^{\circ} \mathrm{C}$. When the temperature of this solution dropped to ca. $50^{\circ} \mathrm{C}$, imidazole $(27.2 \mathrm{~g}, 0.4 \mathrm{~mol})$ and tert-butyldiphenylsilyl chloride $(55 \mathrm{~g}, 52 \mathrm{ml}, 0.2 \mathrm{~mol}$ ) were added under nitrogen, and the whole was stirred at $55-60{ }^{\circ} \mathrm{C}$ for $2.5 \mathrm{~h}$. Extraction 
( $1 \mathrm{M} \mathrm{HCl}-\mathrm{CH}_{2} \mathrm{Cl}_{2}$ ), washing of the organic phase with water, drying, and evaporation furnished a yellowish oil. TLC (hexane-EtOAc, 2:3) showed the product with $R_{f} 0.4$ and impurities moving with the solvent front. Flash chromatography using a gradient of EtOAc in hexane, $2: 3 \rightarrow 1: 1 \rightarrow 3: 2$, gave $\mathbf{3 4}(49 \mathrm{~g}, 63 \%$ ) as a colorless oil.

${ }^{1} \mathrm{H}(300 \mathrm{MHz}$ ): 5.43 (br s, $\mathrm{H} 1 \alpha$, integration of both signals was ca. 3:1), $5.30\left(\mathrm{dd}, J_{12}=3.6 \mathrm{~Hz}, J_{1-\mathrm{OH}}=7.5 \mathrm{~Hz}, \mathrm{H} 1 \beta\right.$, integration of both signals was ca. $3: 1) .{ }^{13} \mathrm{C}(75 \mathrm{MHz}): 135.64,135.60,131.86,131.64$, 130.24, 130.20, 130.13, 128.01, 127.96, 103.5, 97.0, 87.3, 83.1, 78.8, 78.2, 77.9, 76.7, 64.5, 64.1,26.8, 26.7, 19.2, 19.0. HRMS (electrospray) calcd for $\mathrm{C}_{21} \mathrm{H}_{28} \mathrm{O}_{5} \mathrm{Si}+\mathrm{Na}^{+}$: 411.15984, found: 411.15892 .

\subsection{5-0-tert-Butyldiphenylsilyl-1,2-0-isopropylidene- D-arabino-furanose 35}

Compound 34 ( $32 \mathrm{~g}, 82.5 \mathrm{mmol})$ in dry acetone $(360 \mathrm{ml})$, concd $\mathrm{H}_{2} \mathrm{SO}_{4}\left(1.6 \mathrm{ml}\right.$ ), and $\mathrm{CuSO}_{4}$ (dried at ca. $150{ }^{\circ} \mathrm{C}$ for $4 \mathrm{~h}, 36 \mathrm{~g}$ ) were stirred under nitrogen for $7 \mathrm{~h}$. The solids were filtered on a sintered glass. The filtrate was neutralized using cold concd $\mathrm{NH}_{4} \mathrm{OH}$ and the solids were filtered again. TLC showed a spot of $\mathbf{3 5}$ with $R_{f} 0.39$ (in hexane-EtOAc 4:1) and a minor less polar compound. Evaporation and flash chromatography in hexane-EtOAc, 5:1 $\rightarrow 4: 1$, gave 35 ( $25 \mathrm{~g}, 71 \%$ ) as a syrup. For the next oxidation step, a crude olefination product could be used.

$[\alpha]_{\mathrm{D}}^{24}+5.6\left(c 3.2, \mathrm{CHCl}_{3}\right)$; L-enantiomer: ${ }^{20}[\alpha]_{\mathrm{D}}^{24}-5\left(c 1.2, \mathrm{CHCl}_{3}\right)$. ${ }^{1} \mathrm{H}$ (300 MHz): 7.68-7.65 (m, 4H, H aromatic), 7.44-7.35 (m, 6H, H aromatic), 5.87 (d, $\left.J_{12}=4.0 \mathrm{~Hz}, 1 \mathrm{H}, \mathrm{H} 1\right), 4.53\left(\mathrm{~d}, J_{21}=4.0 \mathrm{~Hz}, 1 \mathrm{H}, \mathrm{H} 2\right)$, $4.42(\mathrm{t}, J=3.1 \mathrm{~Hz}, 1 \mathrm{H}, \mathrm{H} 3), 4.06$ (dt, $J=2.4,6.6,6.6 \mathrm{~Hz}, 1 \mathrm{H}), 3.87-3.77$ ( $\mathrm{m}, 2 \mathrm{H}, \mathrm{H} 5$ ), 1.32 and 1.28 (two s, 3H each, isopropylidene Me), 1.06 (s, 9H, $\left.{ }^{t} \mathrm{Bu}\right) .{ }^{13} \mathrm{C}(75 \mathrm{MHz}): 135.61,135.58,133.21,133.17,129.81$, 129.79, 127.8, 112.53, 105.6, 87.5, 87.1, 76.3, 63.7, 26.9, 26.8, 26.1, 19.2. HRMS (electrospray) calcd for $\mathrm{C}_{24} \mathrm{H}_{32} \mathrm{O}_{5} \mathrm{Si}+\mathrm{Na}^{+}: 451.19168$, found: 451.19078 .

\subsection{3-Deoxy-5-0-tert-butyldiphenylsilyl-1,2-0-isopro- pylidene-3-C-methylene-D-threo-furanose 36}

To a stirred suspension of $\mathrm{CrO}_{3}(10.1 \mathrm{~g}, 100 \mathrm{mmol})$ in dry $\mathrm{CH}_{2} \mathrm{Cl}_{2}$ $(200 \mathrm{ml})$ under nitrogen was added pyridine (16.2 $\mathrm{ml}, 200 \mathrm{mmol}$ ). After $25 \mathrm{~min}$, a solution of $35(11.0 \mathrm{~g}, 25.7 \mathrm{mmol})$ in dry $\mathrm{CH}_{2} \mathrm{Cl}_{2}$ $(120 \mathrm{ml})$ was added followed immediately by $\mathrm{Ac}_{2} \mathrm{O}(9.5 \mathrm{ml}$, $100 \mathrm{mmol}$ ). Stirring was continued for $17 \mathrm{~min}$. The reaction was quenched by the addition of $200 \mathrm{ml}$ of $1: 1 \mathrm{EtOAc}$-toluene. The dark supernatant was applied on top of a 60-200 mesh silica gel column prepared in 2:1 EtOAc-toluene. Black residue after decantation was washed twice with 1:1 EtOAc-toluene and the washings were also applied on the column. Elution with 2:1 EtOAc-toluene, evaporation of the volatiles, co-evaporation with xylene, and drying on an oil pump gave colorless oil ( $R_{f} 0.32$ in $6: 1$ hexane-EtOAc), which was solubilized in dry THF and added dropwise to a Wittig reagent prepared from $\mathrm{Ph}_{3} \mathrm{P}^{+} \mathrm{CH}_{3}\left(\mathrm{Br}^{-}\right)(98 \%, 14.3 \mathrm{~g}, 40 \mathrm{mmol})$ suspended in $350 \mathrm{ml}$ of dry THF and $2.5 \mathrm{M} \mathrm{BuLi}$ in hexane $(15.2 \mathrm{ml}, 38 \mathrm{mmol})$ as described for the synthesis of $\mathbf{5}$ and $\mathbf{2 6}$. The cooling bath was removed. After $4 \mathrm{~h}$, TLC showed that the substrate with $R_{f} 0.32$ reacted to form strongly charring new product with $R_{f} 0.58$ in $6: 1$ hexane-EtOAc. Filtration through Celite and evaporation furnished yellow-brown oil, which was solubilized in $\mathrm{CH}_{2} \mathrm{Cl}_{2}$ and washed with water. The organic phase was dried and evaporated. The residue was subjected to flash chromatography in 15:1 hexane-EtOAc to yield $\mathbf{3 6}$ as oil ( $7.9 \mathrm{~g}, 72 \%)$ for two steps.

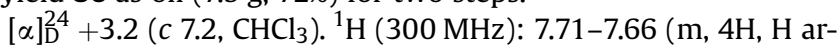
omatic), 7.41-7.33 (m, 6H, H aromatic), $5.80\left(\mathrm{~d}, J_{12}=3.9 \mathrm{~Hz}, 1 \mathrm{H}, \mathrm{H} 1\right)$, 5.45 (dd, $J=0.8,2.0 \mathrm{~Hz}, 1 \mathrm{H}), 5.32(\mathrm{t}, J=1.4 \mathrm{~Hz}, 1 \mathrm{H}), 4.85$ (dt, $J=0.9,0.9$, $3.9 \mathrm{~Hz}, 1 \mathrm{H}), 4.60(\mathrm{tt}, J=1.8,1.8,6.7,6.7 \mathrm{~Hz}, 1 \mathrm{H}), 3.89\left(\mathrm{dd}, J_{5^{\prime}} 4=6.4 \mathrm{~Hz}\right.$, $\left.J_{5^{\prime} 5^{\prime \prime}}=10.0 \mathrm{~Hz}, 1 \mathrm{H}, \mathrm{H}^{\prime}\right), 3.76\left(\mathrm{dd}, J_{5^{\prime \prime}} 4=6.9 \mathrm{~Hz}, J_{5^{\prime \prime} 5^{\prime}}=10.0 \mathrm{~Hz}, 1 \mathrm{H}, \mathrm{H} 5^{\prime \prime}\right)$, 1.34 and 1.31 (two s, $3 \mathrm{H}$ each, isopropylidene $-\mathrm{Me}$ ), $1.06\left(\mathrm{~s}, 9 \mathrm{H},{ }^{t} \mathrm{Bu}\right.$ ).
${ }^{13} \mathrm{C}$ (75 MHz): 145.7, 135.7, 134.8, 133.4, 133.3, 129.7, 129.6, 127.70, $127.67,114.0,113.1,105.4,83.1,81.4,67.2,27.3,26.8,26.5,10.2$. HRMS (electrospray) calcd for $\mathrm{C}_{25} \mathrm{H}_{32} \mathrm{O}_{4} \mathrm{Si}+\mathrm{Na}^{+}$: 447.19677, found: 447.19620 .

\subsection{3-Deoxy-1,2-0-isopropylidene-3-C-methylene- D-threo-furanose 37}

Olefin 36 ( $7.9 \mathrm{~g}, 18.6 \mathrm{mmol})$ in technical grade THF (50 ml) was treated with $1 \mathrm{M} \mathrm{Bu} 4 \mathrm{NF}(20 \mathrm{ml}, 20 \mathrm{mmol})$ for $2 \mathrm{~h}$. TLC showed a new spot with $R_{f} 0.31$ in 3:2 hexane-EtOAc. Evaporation of the solvent and flash chromatography in 55:45 hexane-EtOAc gave 37 (4.5 $\mathrm{g}, 92 \%)$ as oil.

A convenient shortcut to get $\mathbf{3 7}$ is to skip a chromatography after the Wittig reaction and to add $\mathrm{Bu}_{4} \mathrm{NF}$ directly to the THF solution of the crude extract. Thus, starting from $16.2 \mathrm{~g}$ of $35,5.1 \mathrm{~g}$ of the alcohol 37 was obtained in a cumulative yield of $72 \%$ for three steps.

$[\alpha]_{\mathrm{D}}^{24}-28.4\left(c 6.2, \mathrm{CHCl}_{3}\right) .{ }^{1} \mathrm{H}(300 \mathrm{MHz}): 5.85\left(\mathrm{~d}, J_{12}=3.9 \mathrm{~Hz}, 1 \mathrm{H}\right.$, $\mathrm{H} 1$ ), 5.49 (dd, $J=1.0,2.1 \mathrm{~Hz}, 1 \mathrm{H}$ ), 5.27 (t, $J=1.5 \mathrm{~Hz}, 1 \mathrm{H}), 4.90$ (dt, $J=1.0$, $1.0,3.9 \mathrm{~Hz}, 1 \mathrm{H}, \mathrm{H} 2$ ), 4.65 (ddd, $J=2.0,4.1,6.3 \mathrm{~Hz}, 1 \mathrm{H}, \mathrm{H} 4), 3.82$ (dd, $\left.J_{5^{\prime} 4}=7.1 \mathrm{~Hz}, \quad J_{5^{\prime} 5^{\prime \prime}}=11.7 \mathrm{~Hz}, \quad 1 \mathrm{H}, \quad \mathrm{H} 5^{\prime}\right), \quad 3.70 \quad\left(\mathrm{dd}, \quad J_{5^{\prime \prime}} 4=4.2 \mathrm{~Hz}\right.$, $J_{5^{\prime \prime} 5^{\prime}}=11.7 \mathrm{~Hz}, 1 \mathrm{H}, \mathrm{H} 5^{\prime \prime}$ ), 2.70 (br s, exchangeable, $-\mathrm{OH}$ ), 1.56 and 1.36 (two s, 3H each, isopropylidene $-\mathrm{Me}) .{ }^{13} \mathrm{C}(75 \mathrm{MHz}): 145.0,113.7$, $113.4,105.2,83.7,81.2,65.8,27.2,26.5$. HRMS (electrospray) calcd for $\mathrm{C}_{9} \mathrm{H}_{14} \mathrm{O}_{4}+\mathrm{Na}^{+}$: 209.07900, found: 209.07799.

\subsection{4-Hydroxymethyl-3,4-ene-1,2-0-isopropylidene-3- C-methyl-L-glycero-pentofuranose 38 and 3-deoxy-1,2-O- isopropylidene-3-C-methyl-D-lyxo-furanose 39}

Olefin 37 (2.41 g, $12.9 \mathrm{mmol})$ in abs EtOH (20 ml) and $0.1777 \mathrm{~g}$ of $\mathrm{PtO}_{2}$ were hydrogenated in a Parr apparatus at the initial pressure of 38 psi for $2.5 \mathrm{~h}$. TLC showed the olefin 38 with $R_{f} 0.58$, the main compound 39 with $R_{f} 0.36$ (hexane-EtOAc $1: 1$ ), and two more polar unidentified compounds present in small concentration. Compound 39 is slightly more polar than the substrate 37 . Filtration through Celite (attention: dry Pt is pyrophoric), evaporation of the solvent, and flash chromatography in 1:1 hexane-EtOAc gave $\mathbf{3 8}$ $(0.31 \mathrm{~g}, 13 \%)$ and $39(1.73 \mathrm{~g}, 71 \%)$. Both 38 and 39 are oils.

Compound 38. $[\alpha]_{\mathrm{D}}^{24}+4.5\left(\right.$ c $\left.4.8, \mathrm{CHCl}_{3}\right) .{ }^{1} \mathrm{H}(300 \mathrm{MHz}): 5.96(\mathrm{~d}$, $J_{12}=5.3 \mathrm{~Hz}, 1 \mathrm{H}, \mathrm{H} 1$ ), 5.11 (d of unresolved quintettes, four $J=0.9 \mathrm{~Hz}$, $\left.J_{21}=5.3 \mathrm{~Hz}, 1 \mathrm{H}, \mathrm{H} 1\right), 4.17$ (s, 2H, H5), 2.259 (br s, exchangeable, $1 \mathrm{H}$, $-\mathrm{OH}$ ), 1.76, 1.45 and 1.43 (three s, 3H each, isopropylidene -Me, C3$\mathrm{Me}) .{ }^{13} \mathrm{C}(75 \mathrm{MHz}): 151.0,111.9,108.0,103.8,87.2,55.7,28.0,27.9,9.1$. HRMS (electrospray) calcd for $\mathrm{C}_{9} \mathrm{H}_{14} \mathrm{O}_{4}+\mathrm{Na}^{+}$: 209.07900, found: 209.07840.

Compound 39. $[\alpha]_{\mathrm{D}}^{24}+44.4\left(\right.$ c 1.4, $\left.\mathrm{CHCl}_{3}\right) \cdot{ }^{1} \mathrm{H}(300 \mathrm{MHz}): 5.84(\mathrm{~d}$, $\left.J_{12}=3.9 \mathrm{~Hz}, 1 \mathrm{H}, \mathrm{H} 1\right), 4.58\left(\mathrm{dd}, J_{21}=3.9 \mathrm{~Hz}, J_{23}=5.3 \mathrm{~Hz}, 1 \mathrm{H}, \mathrm{H} 1\right), 4.23$ (ddd, $J_{45^{\prime \prime}}=4.0 \mathrm{~Hz}, J_{43}=8.3 \mathrm{~Hz}, J_{45^{\prime}}=9.8 \mathrm{~Hz}, 1 \mathrm{H}, \mathrm{H} 4$ ), 3.94 (dd, $\left.J_{5^{\prime} 4}=10.0 \mathrm{~Hz}, J_{5^{\prime} 5^{\prime \prime}}=11.4 \mathrm{~Hz}, 1 \mathrm{H}, \mathrm{H}^{\prime}\right), 3.52\left(\mathrm{dt}, \mathrm{J}_{5^{\prime \prime}-\mathrm{OH}}=3.9 \mathrm{~Hz}, \mathrm{~J}=10.6\right.$, $10.6 \mathrm{~Hz}, 1 \mathrm{H}, \mathrm{H} 5$ ) [after decoupling of the doublet at $\delta 2.24: 3.96$ (dd, $\left.\left.J_{5^{\prime} 4}=9.8 \mathrm{~Hz}, J_{5^{\prime} 5^{\prime \prime}}=11.5 \mathrm{~Hz}\right), 3.53\left(\mathrm{dd}, J_{5^{\prime \prime} 4}=4.0 \mathrm{~Hz}, J_{5^{\prime \prime} 5^{\prime}}=11.5 \mathrm{~Hz}\right)\right]$, 2.46 ( $\mathrm{m}$ of 14 lines, $J_{32}=5.4 \mathrm{~Hz}, J_{3}-\mathrm{Me}=7.4 \mathrm{~Hz}, J_{34}=8.3 \mathrm{~Hz}, 1 \mathrm{H}, \mathrm{H} 3$ ), $2.24(\mathrm{~d}, J=9.1 \mathrm{~Hz}$, exchangeable, $1 \mathrm{H},-\mathrm{OH}$ ), 1.56 and 1.31 (two s, $3 \mathrm{H}$ each, isopropylidene -Me), 1.10 (d, $J_{\mathrm{Me}-3}=7.4 \mathrm{~Hz}, 3 \mathrm{H}, \mathrm{C} 3-\mathrm{Me}$ ). ${ }^{13} \mathrm{C}$ (75 MHz): 112.1, 105.9, 84.2, 82.3, 62.6, 38.7, 26.5, 25.5, 7.7. HRMS (electrospray) calcd for $\mathrm{C}_{9} \mathrm{H}_{16} \mathrm{O}_{4}+\mathrm{Na}^{+}$: 211.09465, found: 211.09403.

\subsection{3-Deoxy-1,2-0-ispopropylidene-3-C-methyl-5-0- tosyl-D-lyxo-furanose 40}

Alcohol 39 (0.090 g, $0.48 \mathrm{mmol})$ in dry $\mathrm{CH}_{2} \mathrm{Cl}_{2}(10 \mathrm{ml})$, pyridine $(1 \mathrm{ml})$, cat. DMAP, and $\mathrm{TsCl}(0.45 \mathrm{~g}, 2.4 \mathrm{mmol})$ were stored under nitrogen for $24 \mathrm{~h}$. TLC (hexane-EtOAc 1:1) showed a complete conversion to the less polar 40. Extraction $\left(\mathrm{CH}_{2} \mathrm{Cl}_{2}\right.$-dil $\left.\mathrm{HCl}\right)$, 
washing of the organic phase with water, drying, evaporation, and flash chromatography in 3:2 hexane-EtOAc gave the product $(0.11 \mathrm{~g}, 67 \%)$ as a syrup.

${ }^{1} \mathrm{H}(300 \mathrm{MHz}): 7.81(\mathrm{~d}, J=8.2 \mathrm{~Hz}, 2 \mathrm{H}, \mathrm{H}$ aromatic), $7.34(\mathrm{~d}$, $J=8.2 \mathrm{~Hz}, 2 \mathrm{H}, \mathrm{H}$ aromatic), $5.74\left(\mathrm{~d}, J_{12}=3.7 \mathrm{~Hz}, 1 \mathrm{H}, \mathrm{H} 1\right), 4.49(\mathrm{t}$, $J=4.3 \mathrm{~Hz}, 1 \mathrm{H}, \mathrm{H} 2$ ), 4.30-4.19 (unresolved, 3H), 2.34 (s, 4H, H3 and -PhMe), 1.30 and 1.24 (two s, 3H each, isopropylidene -Me), 1.08 (d, $\left.J_{\text {Me-3 }}=7.3 \mathrm{~Hz}, \mathrm{C} 3-\mathrm{Me}\right) .{ }^{13} \mathrm{C}(75 \mathrm{MHz}): 144.7,132.7,129.7,128.0,111.8$, 105.9, 81.9, 80.3, 70.0, 39.2, 26.2, 25.2, 21.5, 8.1. HRMS (electrospray) calcd for $\mathrm{C}_{16} \mathrm{H}_{22} \mathrm{O}_{6} \mathrm{~S}+\mathrm{Na}^{+}: 365.10349$, found: 365.10276 .

\subsection{3,5-Dideoxy-3-C-methyl-D-lyxo-furanose 44}

To a cold (ice bath) solution of the alcohol 39 ( $1.3 \mathrm{~g}, 6.9 \mathrm{mmol})$ in dry $\mathrm{CH}_{2} \mathrm{Cl}_{2}(30 \mathrm{ml})$ and pyridine $(2 \mathrm{ml})$ with magnetic stirring was added dropwise trifluoromethanesulfonic anhydride $(2.4 \mathrm{~g}, 1.4 \mathrm{ml}$, $8.5 \mathrm{mmol})$. After $25 \mathrm{~min}$, extraction was performed $\left(\mathrm{CH}_{2} \mathrm{Cl}_{2}\right.$-dil $\mathrm{HCl}$ ). The organic phase was washed with ice water, dried, filtered through sintered glass, evaporated, and dried on an oil pump to furnish red-orange thick oil. The vacuums were broken using nitrogen in a balloon. All the work-up should be performed rapidly (ca. $30 \mathrm{~min}$ ) to avoid decomposition of the triflate 41. Dry THF $(30 \mathrm{ml})$ was added and the flask was cooled in an ice bath. To the stirred solution was injected $1 \mathrm{M} \mathrm{LiBH}(\mathrm{Et})_{3}$ in THF $(10 \mathrm{ml})$. The initial red-orange color turned yellow immediately. The homogenous mixture was left overnight at rt. Small quantity of unreacted 41 was still present and more $\mathrm{LiBH}(\mathrm{Et})_{3}(3.0 \mathrm{ml})$ was added and the reaction was continued for $24 \mathrm{~h}$ more. TLC showed that the substrate 41 with $R_{f} 0.22$ all reacted forming a faint brown-yellow spot of the substitution product $\mathbf{4 2}$ with $R_{f} 0.38$ (in hexane-EtOAc 10:1) and a black spot at the application point. The reaction mixture was cooled in ice bath and $4 \mathrm{ml}$ of $3 \mathrm{M} \mathrm{H}_{2} \mathrm{SO}_{4}$ was cautiously added (frothing) followed by $10 \mathrm{ml}$ of $1 \mathrm{M} \mathrm{H}_{2} \mathrm{SO}_{4}$. Cooling bath was removed and hydrolysis was continued overnight. TLC (hexaneEtOAc 10:1) showed the presence of a new compound, presumably 43, which was less polar than 42. Exhaustive extraction was performed using $\mathrm{CH}_{2} \mathrm{Cl}_{2}(3 \times)$ and EtOAc $(3 \times)$ as described for $\mathbf{1 4}$ and 15. The extracts were evaporated and co-evaporated several times with $\mathrm{MeOH}$ to break the putative borate $\mathbf{4 3}$ and to release the diol 44. Flash chromatography of the residual yellowish oil in 20:1.3 $\mathrm{CH}_{2} \mathrm{Cl}_{2}-\mathrm{MeOH}$ furnished $44(0.25 \mathrm{~g}, 27 \%)$ as oil, counting on the alcohol 39.

$[\alpha]_{\mathrm{D}}^{24}+32.3$ (c 1.6, $\mathrm{CHCl}_{3}$, after $\left.30 \mathrm{~min}\right) .{ }^{1} \mathrm{H}\left(500 \mathrm{MHz}\right.$, after $\mathrm{D}_{2} \mathrm{O}$ exchange): 5.28 (d, $J_{12}=4.6 \mathrm{~Hz}, \mathrm{H} 1$ ), 5.27 (d, $J_{12}=1.6 \mathrm{~Hz}, \mathrm{H} 1$ ), 4.42 (quintette, $J_{4-\mathrm{Me}}=6.6 \mathrm{~Hz}, J_{43}=6.6 \mathrm{~Hz}, \mathrm{H} 4$ ), 4.12 (quintette, $J_{4-\mathrm{Me}}=$ $\left.6.5 \mathrm{~Hz}, J_{43}=6.5 \mathrm{~Hz}, \mathrm{H} 4\right), 4.10\left(\mathrm{dd}, J_{21}=5.1 \mathrm{~Hz}, J_{23}=6.4 \mathrm{~Hz}, \mathrm{H} 2\right), 4.08$ (dd, $J_{21}=1.5 \mathrm{~Hz}, J_{23}=5.4 \mathrm{~Hz}, \mathrm{H} 2$ ), 2.46 (m of 10 lines, $J_{32}=5.5 \mathrm{~Hz}$, $J_{34}=7.3 \mathrm{~Hz}, J_{3}-\mathrm{Me}=7.3 \mathrm{~Hz}, \mathrm{H} 3$ ), 2.28 ( $\mathrm{m}$ of 6 lines, $J=7.0 \mathrm{~Hz}, \mathrm{H} 3$ ), 1.22 $\left(\mathrm{d}, J_{\mathrm{Me}-\mathrm{H}}=6.6 \mathrm{~Hz}\right.$, terminal $\left.-\mathrm{Me}\right), 1.17\left(\mathrm{~d}, J_{\mathrm{Me}-\mathrm{H}}=6.6 \mathrm{~Hz}\right.$, terminal -Me), 1.02 (d, $\left.J_{\mathrm{Me}-\mathrm{H}}=7.3 \mathrm{~Hz}, \mathrm{C} 2-\mathrm{Me}\right), 0.98$ (d, $\left.J_{\mathrm{Me}-\mathrm{H}}=7.3 \mathrm{~Hz}, \mathrm{C} 2-\mathrm{Me}\right)$. ${ }^{13} \mathrm{C}$ (75 MHz): 101.6, 96.5, 79.1, 77.1, 76.5, 73.5, 39.0, 38.2, 17.9, 17.6, 8.2, 7.5. HRMS (EI) calcd for $\mathrm{C}_{6} \mathrm{H}_{12} \mathrm{O}_{3}-\mathrm{CH}_{3}$ : 117.05517, found: 117.05518 .

\subsection{2-Naphthylmethyl (3R)-hydroxy-(2S)-methylbutanoate 48}

To a magnetically stirred solution of the diol $44(0.16 \mathrm{~g}$, $1.6 \mathrm{mmol})$ in EtOH $(20 \mathrm{ml})$ was added $\mathrm{NaIO}_{4}(0.38 \mathrm{~g}, 1.8 \mathrm{mmol})$ in $4 \mathrm{ml}$ of distd $\mathrm{H}_{2} \mathrm{O}$. The mixture turned opaque immediately. After $2 \mathrm{~h}$, TLC $\left(\mathrm{CH}_{2} \mathrm{Cl}_{2}-\mathrm{MeOH} 20: 1.3\right)$ showed that all substrate has reacted. The solids were filtered on a sintered glass and EtOH was evaporated. To the residue was added $\mathrm{CH}_{3} \mathrm{CN}(20 \mathrm{ml})$. Small quantity of the precipitated solids was again removed by filtration. To the resulting clear solution was added $\mathrm{NaClO}_{2}(80 \%, 0.38 \mathrm{~g}$, $3.2 \mathrm{mmol}$ ) solubilized in a minimum volume of distd $\mathrm{H}_{2} \mathrm{O}$ followed by $\mathrm{NaH}_{2} \mathrm{PO}_{4} \cdot 2 \mathrm{H}_{2} \mathrm{O}(0.076 \mathrm{~g}, 0.49 \mathrm{mmol})$ in minimum volume of
$\mathrm{H}_{2} \mathrm{O}$ and $35 \% \mathrm{H}_{2} \mathrm{O}_{2}(0.3 \mathrm{ml})$ in this order. The resulting yellow homogenous mixture was stirred for $30 \mathrm{~min}$. TLC at this stage showed the main spot of $\mathbf{4 6}$ and much less intense spot of the more polar $\mathbf{4 7}$. Revelation was done using a bromocresol green reagent: both $\mathbf{4 5}$ and $\mathbf{4 6}$ formed yellow spots on a blue background. The mixture was passed through a bed of Celite, evaporated, and solubilized in distd $\mathrm{CH}_{2} \mathrm{Cl}_{2}$. Addition of freshly prepared 2-naphthyldiazomethane $\mathbf{2 3}$ was continued until evolution of nitrogen subsided and a reddish color persisted. The solvent was evaporated. The residue was solubilized in $\mathrm{MeOH}(15 \mathrm{ml})$ and seven drops of concd $\mathrm{NH}_{4} \mathrm{OH}$ were added. After $40 \mathrm{~min}$, TLC (hexane-EtOAc 3:1) showed an UV absorbing spot of $\mathbf{4 8}$ with $R_{f} 0.34$ accompanied by several much less polar spots. Spraying with a $\mathrm{CrO}_{3}-\mathrm{H}_{2} \mathrm{SO}_{4}$ system and heating reveals $\mathbf{4 8}$ as a reddish-brown spot. Evaporation of the solvent and flash chromatography in 3:1 hexane-EtOAc furnished $\mathbf{4 8}$ as a glassy material, $0.17 \mathrm{~g}, 54 \%$ counting on 44.

$[\alpha]_{\mathrm{D}}^{24}+0.5\left(\right.$ c $\left.6, \mathrm{CHCl}_{3}\right) .{ }^{1} \mathrm{H}\left(500 \mathrm{MHz}\right.$, after $\mathrm{D}_{2} \mathrm{O}$ exchange $): 7.84-$ 7.81 ( $\mathrm{m}, 4 \mathrm{H}, \mathrm{H}$ aromatic), 7.50-7.43 (m, 3H, $\mathrm{H}$ aromatic), 5.30 (s, 2H, $-\mathrm{OCH}_{2}-$ ), 4.09 (dq, $J_{32}=4.0 \mathrm{~Hz}, J_{3-\mathrm{Me}}=6.3 \mathrm{~Hz}, 1 \mathrm{H}, \mathrm{H} 3$ ), 2.62 (br s, residual $\mathrm{OH}), 2.57\left(\mathrm{dq}, J_{23}=3.9 \mathrm{~Hz}, J_{2}-\mathrm{Me}=7.2 \mathrm{~Hz}, 1 \mathrm{H}, \mathrm{H} 2\right), 1.22\left(\mathrm{~d}, J_{\mathrm{Me}-2}=\right.$ $7.3 \mathrm{~Hz}, 3 \mathrm{H}, \mathrm{C} 2-\mathrm{Me}$ ), 1.17 (d, J $J_{\mathrm{Me}-3}=6.4 \mathrm{~Hz}, 3 \mathrm{H}$, terminal Me). ${ }^{13} \mathrm{C}$ (125 MHz): 175.70, 133.10, 133.07, 128.43, 127.93, 127.67, 127.35, $126.32,126.30,125.70,67.95,66.50,45.57,19.80,10.98$. HRMS (electrospray) calcd for $\mathrm{C}_{16} \mathrm{H}_{18} \mathrm{O}_{3}+\mathrm{Na}^{+}$: 281.11483, found: 281.11477.

\subsection{5-O-tert-Butyldiphenylsilyl-3-deoxy-1,2-0-isopro- pylidene-3-C-methylene-L-threo-pentofuranose 50}

Compound $\mathbf{5 0}^{21}$ was obtained from $\mathbf{4 9}^{20,21}$ following the directions for the D-enantiomer $\mathbf{3 5}$ in 56\% yield for two steps, rather than using Tebbe's reagent or Peterson's olefination as described before. $^{21}$

$[\alpha]_{\mathrm{D}}-3.3\left(\right.$ c $\left.6, \mathrm{CHCl}_{3}\right)$. For NMR data see 36.

\subsection{5-O-tert-Butyldiphenylsilyl-3,4-ene-1,2-0- isopropylidene-3-C-methyl-D-glycero-pentofuranose 51 and 5- o-tert-butyldiphenylsilyl-3-deoxy-1,2-O-isopropylidene-3-C- methyl-t-lyxo-furanose 52}

Olefin 50 (0.41 g, $1.37 \mathrm{mmol})$ in EtOH $(25 \mathrm{ml})$ and 10\% Pd-C $(0.05 \mathrm{~g})$ were hydrogenated at the initial pressure of $40 \mathrm{psi}$ in a Parr apparatus for $5 \mathrm{~h}$. TLC showed traces of unreacted substrate and a less polar compound $\mathbf{5 1}$ with $R_{f} 0.46$ and the product $\mathbf{5 2}$ with $R_{f}$ 0.19 (hexane-EtOAc 15:1). Filtration through Celite, evaporation, and flash chromatography in a gradient of EtOAc in hexane, $1: 15 \rightarrow 2: 15$, gave $\mathbf{5 1}$ (oil, $0.19 \mathrm{~g}, 46 \%$ ) and $\mathbf{5 2}$ (oil, $0.15 \mathrm{~g}, 36 \%$ ).

Compound 51. $[\alpha]_{\mathrm{D}}^{24}+2.7\left(c 2.3, \mathrm{CHCl}_{3}\right) .{ }^{1} \mathrm{H}(300 \mathrm{MHz}): 7.71-7.69$ (m, 4H, H aromatic), 7.41-7.36 (m, 6H, H aromatic), $5.92(\mathrm{~d}$, $J_{12}=5.3 \mathrm{~Hz}, 1 \mathrm{H}, \mathrm{H} 1$ ), 5.01 (d, $J_{12}=5.3 \mathrm{~Hz}, 1 \mathrm{H}, \mathrm{H} 2$ ), 4.19 (s, 2H, H5), $1.61(\mathrm{~s}, 3 \mathrm{H})$ and $1.45(\mathrm{~s}, 6 \mathrm{H})$ : isopropylidene Me and C3-Me, 1.05 (s, $\left.9 \mathrm{H},{ }^{t} \mathrm{Bu}\right) .{ }^{13} \mathrm{C}(75 \mathrm{MHz}): 151.1,135.70,135.67,133.21,133.16,129.8$, 127.8, 111.7, 108.0, 103.9, 87.4, 57.5, 28.0, 26.8, 19.3, 9.2. HRMS (electrospray) calcd for $\mathrm{C}_{25} \mathrm{H}_{32} \mathrm{O}_{4} \mathrm{Si}+\mathrm{Na}^{+}$: 447.19622, found: 447.19566.

Compound 52. $[\alpha]_{\mathrm{D}}^{24}-32.8\left(\right.$ c 3.8, $\left.\mathrm{CHCl}_{3}\right) .{ }^{1} \mathrm{H}(300 \mathrm{MHz}): 7.69-$ $7.66(\mathrm{~m}, 4 \mathrm{H}, \mathrm{H}$ aromatic), 7.43-7.33 (m, 6H, H aromatic), 5.75 (d, $\left.J_{12}=3.9 \mathrm{~Hz}, 1 \mathrm{H}, \mathrm{H} 1\right), 4.49\left(\mathrm{t}, J_{12}=J_{23}=4.5 \mathrm{~Hz}, 1 \mathrm{H}, \mathrm{H} 2\right), 4.24(\mathrm{dt}$, $\left.J_{45^{\prime \prime}}=5.6 \mathrm{~Hz}, J_{43}=7.5 \mathrm{~Hz}, J_{45^{\prime}}=7.6 \mathrm{~Hz}, 1 \mathrm{H}, \mathrm{H} 4\right), 3.97\left(\mathrm{dd}, J_{5^{\prime}} 4=7.6 \mathrm{~Hz}\right.$, $\left.J_{5^{\prime} 5^{\prime \prime}}=10.2 \mathrm{~Hz}, 1 \mathrm{H}, \mathrm{H} 5^{\prime}\right), 3.77\left(\mathrm{dd}, J_{5^{\prime \prime}}{ }^{\prime}=5.3 \mathrm{~Hz}, J_{5^{\prime \prime} 5^{\prime}}=10.3 \mathrm{~Hz}, 1 \mathrm{H}, \mathrm{H} 5^{\prime \prime}\right)$, $2.42\left(\mathrm{ddq}, J_{32}=4.8 \mathrm{~Hz}, J_{34}=7.4 \mathrm{~Hz}, J_{3}-\mathrm{Me}=7.3 \mathrm{~Hz}, 1 \mathrm{H}, \mathrm{H} 3\right), 1.27$ and 1.24 (two s, 3H each, isopropylidene Me), 1.19 (d, $J_{\mathrm{Me}-3}=7.3 \mathrm{~Hz}, 3 \mathrm{H}$, C3-Me), 1.05 (s, 9H, $\left.{ }^{t} \mathrm{Bu}\right) .{ }^{13} \mathrm{C}(75 \mathrm{MHz}): 135.58,135.54,133.6,133.4$, 129.54, 129.52, 127.6, 111.6, 105.8, 84.2, 82.5, 64.3, 39.3, 26.8, 26.4, 25.5, 19.1, 8.6. HRMS (electrospray) calcd for $\mathrm{C}_{25} \mathrm{H}_{34} \mathrm{O}_{4} \mathrm{Si}+\mathrm{Na}^{+}$: 449.21187, found: 449.21146 . 
3.29. 3-Deoxy-1,2-O-isopropylidene-3-C-methylene-Lthreo-pentofuranose 53

Compound $\mathbf{5 3}$ was obtained from $\mathbf{5 0}$ as described for its D-enantiomer 37 in $95 \%$ yield.

$[\alpha]_{\mathrm{D}}^{24}+28.8$ ( c 5, $\mathrm{CHCl}_{3}$ ). For NMR data see 37. HRMS (electrospray) calcd for $\mathrm{C}_{9} \mathrm{H}_{14} \mathrm{O}_{4}+\mathrm{Na}^{+}$: 209.07845, found: 209.07787.

\subsection{3-Deoxy-1,2-0-isopropylidene-3-C-methyl-L-lyxo- furanose 54}

Compound $\mathbf{5 3}$ was subjected to hydrogenation over Adam's catalyst as described for its D-enantiomer $\mathbf{3 7}$ to furnish $\mathbf{5 4}$ in 83\% yield. A different batch of Adam's catalyst was used than in the case of 37 and no migration of the $\mathrm{C}=\mathrm{C}$ bond to the $\mathrm{C} 3-\mathrm{C} 4$ position was seen.

$[\alpha]_{\mathrm{D}}^{24}-44.4\left(\right.$ c 2.5, $\left.\mathrm{CHCl}_{3}\right)$. For NMR data see 39. HRMS (EI) calcd for $\mathrm{C}_{9} \mathrm{H}_{16} \mathrm{O}_{4}-\mathrm{Me}$ : 173.08137, found: 173.08187.

\subsection{3,5-Dideoxy-3-C-methyl-L-lyxo-furanose 55}

Compound 55 was obtained as described for its D-enantiomer 44 in $27 \%$ cumulative yield.

$[\alpha]_{\mathrm{D}}^{24}-38.1$ ( c 3.2, $\mathrm{CHCl}_{3}$, after $30 \mathrm{~min}$ ). For NMR data see 44. HRMS (EI) calcd for $\mathrm{C}_{6} \mathrm{H}_{12} \mathrm{O}_{3}-\mathrm{Me}: 117.05517$, found: 117.05431 .

\subsection{2-Naphthylmethyl (3S)-hydroxy-(2R)-methyl- butanoate 56}

Compound $\mathbf{5 6}$ was prepared from $\mathbf{5 5}$ as described for its enantiomer $\mathbf{4 8}$ in $63 \%$ cumulative yield.

$[\alpha]_{D}^{24}-0.2\left(\right.$ c $\left.3, \mathrm{CHCl}_{3}\right)$. For NMR data see 48. HRMS (electrospray) calcd for $\mathrm{C}_{16} \mathrm{H}_{18} \mathrm{O}_{3}+\mathrm{H}^{+}:$259.13286, found: 259.13281 .

\subsection{3-Deoxy-1,2-O-ispropylidene-3-C-methylene-5-O- tosyl-L-threo-pentofuranose 57}

Compound $53(0.22 \mathrm{~g}, 1.2 \mathrm{mmol})$ in dry $\mathrm{CH}_{2} \mathrm{Cl}_{2}(10 \mathrm{ml})$, pyridine $(1 \mathrm{ml})$, cat. DMAP, and TsCl $(0.5 \mathrm{~g}, 2.6 \mathrm{mmol})$ were left for $48 \mathrm{~h}$. TLC showed a new compound with $R_{f} 0.46$ in 3:1 hexane-EtOAc. Extraction $\left(\mathrm{CH}_{2} \mathrm{Cl}_{2}\right.$-dil $\left.\mathrm{HCl}\right)$, drying, evaporation, and flash chromatography using a gradient of EtOAc in hexane, $1: 4 \rightarrow 1: 3$, furnished $0.29 \mathrm{~g}, 72 \%$ of glassy 57.

${ }^{1} \mathrm{H}$ (300 MHz): $7.81-7.78$ (m, 2H), 7.35 (br s, $1 \mathrm{H}, \mathrm{H}$ aromatic), 7.33 (br s, $1 \mathrm{H}, \mathrm{H}$ aromatic), 5.77 (d, $\left.J_{12}=3.7 \mathrm{~Hz}, 1 \mathrm{H}, \mathrm{H} 1\right), 5.50$ (dd, $J=0.8$, $\left.1.9 \mathrm{~Hz}, 1 \mathrm{H},=\mathrm{CH}_{2}\right), 5.30\left(\mathrm{t}, J=1.3 \mathrm{~Hz}, 1 \mathrm{H},=\mathrm{CH}_{2}\right), 4.81(\mathrm{dt}, J=0.9$, $0.9 \mathrm{~Hz}, J_{21}=3.7 \mathrm{~Hz}, 1 \mathrm{H}, \mathrm{H} 2$ ), 4.68 (q of triplets, $J=1.8,1.8 \mathrm{~Hz}$, $\left.J_{45^{\prime \prime}}=5.4 \mathrm{~Hz}, J_{45^{\prime}}=7.3 \mathrm{~Hz}, 1 \mathrm{H}, \mathrm{H} 4\right), 4.19\left(\mathrm{dd}, J_{5^{\prime} 4}=7.4 \mathrm{~Hz}, J_{5^{\prime} 5^{\prime \prime}}=10.1 \mathrm{~Hz}\right.$, $\left.1 \mathrm{H}, \mathrm{H} 5^{\prime}\right), 4.10\left(\mathrm{dd}, J_{5^{\prime \prime}} 4=5.3 \mathrm{~Hz}, J_{5^{\prime \prime} 5^{\prime}}=10.1 \mathrm{~Hz}, 1 \mathrm{H}, \mathrm{H} 5^{\prime \prime}\right), 2.44(\mathrm{~s}, 3 \mathrm{H}$, $\mathrm{Ph}-\mathrm{Me}$ ), 1.34 and 1.30 (two $\mathrm{s}, 3 \mathrm{H}$ each, isopropylidene $\mathrm{Me}$ ). ${ }^{13} \mathrm{C}$ (75 MHz): 144.8, 143.6, 132.7, 129.8, 128.0, 115.4, 113.4, 105.6, 80.9, 79.5, 71.8, 27.0, 16.2, 21.6. HRMS (electrospray) calcd for $\mathrm{C}_{16} \mathrm{H}_{20} \mathrm{O}_{6} \mathrm{~S}+\mathrm{Na}^{+}:$363.08730, found: 363.08764 .

\section{Acknowledgements}

Mr. Bert Demarsin (Department of Chemistry, KULeuven) is acknowledged for the electron impact high resolution mass measurements, and Mrs. Stephanie Vandenwaeyenbergh and Prof. Jef Rozenski (Rega Institute) for the electrospray HRMS. Dr. Natalya
Dubyankova and Mr. Luc Baudemprez (Rega Institute) are thanked for the $500 \mathrm{MHz}$ spectra.

\section{References and notes}

1. Smirnov, V. V.; Churkina, L. N.; Perepnikhatka, V. I.; Mukvich, N. S.; Garagulya, A. D.; Kiprianova, E. A.; Kravets, A. N.; Dovzhenko, S. A. Appl. Biochem. Microbiol 2000, 36, 46 and references cited therein.

2. Smirnov, V. V.; Kiprianova, E. A.; Gvozdyak, O. R.; Garagulya, A. D.; Churkina, L. N.; Proskuryakova, N. B.; Kharchenko, L. A. Zh. Mikrobiol. Epidemiol. Immunobiol. 1999, 5, 77.

3. Witte, W.; Cuny, C. Mollmann, U. Chemother. J. 1997, 6, 48; Chem. Abstr. 1997, $127,63039$.

4. Kamikiri, K.; Myazaki, S.; Nagai, K.; Suzuki, Y.; Yamaguchi, Y.; Shibazaki, M.; Washisaki, S.; Tokunaga, T.; Butsudo, R.; Ratona, M. R. Patent JP 06319574A 1994.

5. Kamigiri, K.; Suzuki, Y.; Shibazaki, M.; Morioka, M.; Suzuki, K.-I.; Tokunaga, T.; Seitawan, B.; Rantiatmodjo, R. M. J. Antibiot. 1996, 49, 136.

6. Tokunaga, Y.; Kamigiri, K.; Orita, M.; Nishikawa, T.; Shimizu, M.; Kaniwa, H. J. Antibiot. 1996, 49, 140.

7. Doboszewski, B.; Herdewijn, P. Tetrahedron Lett. 2008, 49, 1331.

8. Neri, C.; Williams, J. M. J. Adv. Synth. Catal. 2003, 345, 835.

9. Neri, C.; Williams, J. M. J. Tetrahedron Lett. 2002, 43, 4257.

10. Roush, W. R.; Bannister, T. D.; Wendt, M. D.; Jablonowaski, J. A.; Scheidt, K. A. J. Org. Chem. 2002, 67, 4275.

11. Vicario, J. L.; Badia, D.; Dominguez, E.; Rodriguez, M.; Carrillo, J. J. Org. Chem. 2000, 65, 3754.

12. Harris, R. C.; Cutter, A. L.; Weisman, K. J.; Hanefeld, U.; Timoney, M. C.; Staunton, J. J. Chem. Res. S. 1998, 283.

13. Lützen, A.; Köll, P. Tetrahedron: Asymmetry 1997, 8, 1193.

14. Raimundo, B. C.; Heathcock, C. H. Synlett 1995, 1213.

15. Hoffmann, R. W.; Dresely, S. Chem. Ber. 1989, 122, 903

16. Davis, S. G.; Dordor-Hedgecock, J. M.; Warner, P. Tetrahedron Lett. 1985, 26, 2125.

17. Tai, A.; Morimoto, N.; Yoshikawa, M.; Uehara, K.; Sugimura, T.; Kikukawa, T. Agric. Biol. Chem. 1990, 54, 1753.

18. Tai, A.; Imaida, M. Bull. Chem. Soc. Jpn. 1978, 51, 1114.

19. Maskens, K.; Polgar, N. J. Chem. Soc., Perkin Trans. 1 1973, 109.

20. Dahlman, O.; Garegg, P. J.; Mayer, H.; Schramek, S. Acta Chem. Scand. B 1986 $40,15$.

21. Doboszewski, B.; Herdewijn, P. Tetrahedron 1996, 52, 1651

22. Martin, O. R.; Nabinger, R. C.; Ali, Y.; Vyas, D. M.; Szarek, W. A. Carbohydr. Res. 1983, 121, 302

23. Dang, H.-S.; Roberts, B. P. J. Chem. Soc., Perkin Trans. 1 2002, 1161.

24. Ikawa, T.; Hattori, K.; Sajiki, H.; Hirota, K. Tetrahedron 2004, 60, 6901.

25. Ikawa, T.; Sajiki, H.; Hirota, K. Tetrahedron 2004, 60, 6189.

26. Xie, X.; Berges, D. A.; Robins, M. J. J. Org. Chem. 1996, 61, 5178

27. Robins, M. J.; Doboszewski, B.; Timoshchuk, V. A.; Peterson, M. A. J. Org. Chem. 2000, 65, 2939.

28. De Armas, H. N.; Doboszewski, B.; Herdewijn, P.; Blaton, N. Acta Crystallogr 2007, E63, 2678.

29. Tronchet, J. M. J.; Graf, R. Helv. Chim. Acta 1972, 55, 1141.

30. Dahlhoff, W. V.; Köster, R. Heterocycles 1982, 18, 421.

31. Szarek, W. A.; Zamojski, A.; Tiwari, K. N.; Ison, E. R. Tetrahedron Lett. 1986, 27 3827.

32. Sen, S. E.; Roach, S. L.; Boggs, J. K.; Ewing, G. J.; Magrath, J. J. Org. Chem. 1997, 62 6684.

33. Dalcanale, E.; Montanari, F. J. Org. Chem. 1986, 51, 567.

34. Krebs, K. G.; Heusser, D.; Wimmer, H. Thin-Layer Chromatography: A Laboratory Handbook; Stahl, E., Ed.; Springer: Berlin, 1969; p 854.

35. Touchstone, J. C.; Dobbins, M. F. Practice of Thin Layer Chromatogaphy, 2nd ed; Wiley Interscience: New York, NY, 1983; p 163.

36. Asis, S. E.; Bruno, A. M.; Martinez, A. R.; Sevilla, M. W.; Gaozza, C. H.; Romano, A. M.; Coussio, J. D.; Ciccia, G. H. Il Farmaco 1990, 54, 517.

37. Miller, J. B. J. Org. Chem. 1959, 25, 560.

38. Gutsche, C. D.; Jason, E. F. J. Am. Chem. Soc. 1956, 78, 1184

39. Smets, G.; Boutemburg, A. J. Polym. Sci., Part A1 1970, 8, 3251.

40. Matthes, D. P.; Purdy, W. C. Anal. Chim. Acta 1979, 109, 61

41. Moravcová, J.; Capková, J.; Stanek, J. Carbohydr. Res. 1994, 263, 61.

42. Yoshimura, Y.; Sano, T.; Matsuda, A.; Ueda, T. Chem. Pharm. Bull. 1988, 36 162.

43. Martin, O. R.; Rao, S. P.; El-Shenawy, H. A.; Kurz, K. G.; Cutler, A. B. J. Org. Chem $1988,53,3287$

44. Smith, M. B.; March, J. March's Advanced Organic Chemistry, 6th ed.; WileyInterscience: New Jersey, NJ, 2007; p 1053.

45. Keith, J. Comprehensive Organic Functional Group Transformations; Katritzky, A. R. Meth-Cohn, O., Rees, C. W., Eds.; Pergamon: Oxford, 1995; p 71.

46. Streicher, H.; Meisch, J.; Bohner, C. Tetrahedron 2001, 57, 8851. 